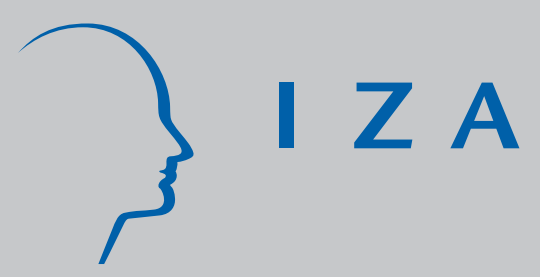

IZA DP No. 1495

Following Germany's Lead:

Using International Monetary Linkages to Identify the Effect of Monetary Policy on the Economy

\author{
Julian di Giovanni \\ J ustin McCrary \\ Till von Wachter
}

February 2005 


\title{
Following Germany's Lead: Using International Monetary Linkages to Identify the Effect of Monetary Policy on the Economy
}

\author{
Julian di Giovanni \\ IMF \\ Justin McCrary \\ University of Michigan \\ Till von Wachter \\ Columbia University and IZA Bonn
}

Discussion Paper No. 1495

February 2005

IZA

P.O. Box 7240

53072 Bonn

Germany

Phone: +49-228-3894-0

Fax: +49-228-3894-180

Email: iza@iza.org

\begin{abstract}
Any opinions expressed here are those of the author(s) and not those of the institute. Research disseminated by IZA may include views on policy, but the institute itself takes no institutional policy positions.
\end{abstract}

The Institute for the Study of Labor (IZA) in Bonn is a local and virtual international research center and a place of communication between science, politics and business. IZA is an independent nonprofit company supported by Deutsche Post World Net. The center is associated with the University of Bonn and offers a stimulating research environment through its research networks, research support, and visitors and doctoral programs. IZA engages in (i) original and internationally competitive research in all fields of labor economics, (ii) development of policy concepts, and (iii) dissemination of research results and concepts to the interested public.

IZA Discussion Papers often represent preliminary work and are circulated to encourage discussion. Citation of such a paper should account for its provisional character. A revised version may be available directly from the author. 


\section{ABSTRACT \\ Following Germany's Lead: Using International Monetary Linkages to Identify the Effect of Monetary Policy on the Economy*}

Forward-looking behavior on the part of the monetary authority leads least squares estimates to understate the true growth consequences of monetary policy interventions. We present instrumental variables estimates of the impact of interest rates on real output growth for several European countries, using German interest rates as the instrument. We compare this identification strategy to the vector autoregression approach, and give an interpretation of our estimates that is appropriate in a dynamic context. Moreover, we show that the difference between least squares and instrumental variables estimates provides bounds for the degree of endogeneity in monetary policy. The results confirm a considerable downward bias of estimates that do not account for potential forward-looking monetary policy decisions. The bias is higher for countries whose monetary policy was more independent of Germany.

JEL Classification: E52, J60

Keywords: monetary policy, forward looking bias, instrumental variables

Corresponding author:

Til von Wachter

Department of Economics

Columbia University

1022 International Affairs Building

420 West 118th Street

New York, NY 10027

USA

Email:vw2112@columbia.edu

\footnotetext{
* We thank Jean Boivin, Maurice Obstfeld, David Romer, Andrew Rose, and participants at the 2004 NBER Summer Workshop in Monetary Economics and the Federal Reserve Bank of Chicago for helpful comments. Any errors are our own. This paper should not be reported as representing the views of the IMF. The views expressed are those of the authors and do not necessarily reflect the views of the IMF or IMF policy.
} 


\section{Introduction}

Whether monetary policy affects the real economy is a recurring and debated question in macroeconomics. Part of the difficulty in giving an empirical answer to the question arises directly from the nature of the objectives of monetary authorities. If central banks try to smooth expected output fluctuations ensuing monetary policy decisions will be forwardlooking. Simple comparisons of real output growth between episodes of contractionary and expansionary monetary policy are then likely to understate the true consequences of monetary policy interventions. In this paper, we present instrumental variables estimates of the effect of monetary policy on real output growth for several European countries, using German interest rates as the instrument. This improves upon simple estimates if German monetary policy is an important determinant of other European countries' interest rates and if shocks to output growth are not perfectly correlated. The instrumental variable (IV) approach directly controls for endogenous policy responses, provides estimates of the degree of endogeneity, and can be applied whenever central banks follow alternative policy goals that are not directly related to the expected paths of output or inflation. Our results suggest that IV estimates substantially reduce the bias due to forward-looking monetary policy, particularly for larger European countries with a higher degree of monetary policy independence.

The standard approach for estimating the effects of monetary policy on the real economy is the vector autoregression model (VAR). The VAR framework aims at controlling for forward-looking policy decisions by including a sufficient number of lags of output, interest rates, and prices (e.g., Bernanke and Mihov 1998). Recently, Bernanke, Boivin and Eliasz (2003)) have extended this strategy to condition on a large number of observable characteristics using factor analysis. The VAR approach to estimating the effects of monetary policy has proven to be a very flexible tool for applied researchers, and has been implemented for a vast range of time periods, outcome variables, and control variables. However, as is widely appreciated, the VAR approach has to assume that the information sets of the monetary 
authority and researchers are the same. A drawback of the VAR approach is that this assumption cannot be validated directly. The two-stage least squares estimates we present in this paper aim to eliminate any remaining bias due to forward looking policy directly by controlling the source of variation in monetary policy. Since we do not make assumptions on the monetary authority's information set, our results can be used to assess the extent of information of the central bank unknown to the researcher. Beyond a diagnostic tool, the instrumental variables estimates we present yield a complementary set of estimates of the effect of monetary policy based on straightforward identifying assumptions. Comparisons of instrumental variables and more naïve least squares estimates allow us to relate the degree of bias due to forward-looking monetary policy, which we additionally relate to underlying macroeconomic factors, as explained in more detail below.

The two-stage least squares estimates we present can be shown to be a simple extension of the classic VAR model. Specifically, two-stage least squares estimates are based on less restrictive identification assumptions in a system of simultaneous equations that also nests the classic approach. ${ }^{1}$ Our approach exploits variation in monetary policy arising from goals of the monetary authority that are not related to short term output stabilization. We thus embed an explicit source of exogenous variation in monetary policy within a dynamic system of equations. We thereby formalize the main ideas behind the historical analyses of Friedman and Schwartz (1963) and Romer and Romer (1989). The estimates we present can thus also be interpreted as providing a bridge between the estimates of the effects of monetary policy using VAR methods and those using the 'narrative' approach.

Our identification strategy takes advantage of international monetary linkages, which limit to some extent a country's ability to engage in forward-looking monetary policy. Specifically, we argue that many European countries followed Germany's lead in setting their monetary policy during our sample period, 1973-1998, making Germany effectively the 'anchor'

\footnotetext{
${ }^{1}$ It is also related to the block exogeneity approach to vector autoregression (see, for example, Cushman and Zha (1997)).
} 
country. This leader-follower relationship was particularly relevant during the existence of the European Monetary System (EMS) and the Exchange Rate Mechanism (ERM). Furthermore, even if a country was not part of the system, its policymakers may still have followed the Bundesbank's policy so as to import inflation credibility. ${ }^{2}$ As such, it is not surprising that German interest rates are highly predictive of interest rates for other European countries. That pegged exchange rates limit monetary independence of central banks has been a classic theme in international monetary economics. Although estimates of the degree of monetary dependence differs (von Hagen and Fratianni 1990), we view the main point to be uncontroversial. Our 'first-stage' relationship between domestic and base country interest rates receives support from the recent empirical literature. Shambaugh (2004) and Obstfeld, Shambaugh and Taylor (2004a) argue that exchange rate pegs indeed limit monetary policy. Our results are also consistent with recent estimates of the European Central Bank's reaction functions in Clarida and Gertler (1997) and Richard Clarida and Gertler (1998).

The application of instrumental variables techniques in a cross-country setting is made difficult by the fact that most macroeconomic variables co-move to at least a certain degree. In our application correlation of output and inflation across countries induce co-movements of interest rates that may lead to a remaining bias of the instrumental variable bias estimator. An advantage of our approach is that it allows us to characterize the remaining bias of IV explicitly in terms of interpretable and potentially estimable parameters. In the empirical analysis we exploit the derived relationship to relate the size of the remaining bias to the distance between countries, the degree of trade linkages, and bilateral exchange rate volatility with respect to the Deutschmark, which is used as a measure of monetary independence. To examine the influence of differences in monetary arrangements on the relative biases of OLS and IV, we also provide separate estimates for the period of the Exchange Rate Mechanism. A potential shortcoming of our approach is that we are unable to estimate the time path of

\footnotetext{
${ }^{2}$ See Giavazzi and Giovannini (1987) for evidence that Germany was the anchor country during the EMS period. Giavazzi and Pagano (1988) offer a theoretical model that describes why countries may submit themselves to the EMS for low-inflation discipline.
} 
the dynamic impact of a monetary tightening. However, as discussed in more detail below, our static estimate measures a parameter of economic interest. When viewed in the context of a dynamic model, it is a reduced-form parameter summarizing the impact of an episode of contractionary monetary policy (see Section 2).

Our estimates suggest that the effect of a 5 percentage point increase in interest rates is a recessionary contraction in annual real growth of 2 to 3 percentage points. This is in contrast to naïve OLS estimates, which suggest a more modest slowdown of 0.5 to 1 percentage points. These results suggest that the monetary authorities in these countries are indeed forwardlooking. However, the degree of forward-looking behavior is heterogeneous; the least squares bias is stronger for countries that are less tied to Germany economically, and who have greater scope for independent and thus potentially endogenous monetary policy.

The remainder of the paper is organized as follows. Section 2 describes the identification strategy, compares our approach to simple vector autoregression estimates, relates our static model to the results of a dynamic one, and relates the the size of the bias to potential economic fundamentals particular to the time period and country-sample that we examine. Section 3 presents the main empirical results, and Section 4 concludes.

\section{Identification strategy}

If central banks choose monetary policy taking into account information about future output growth, simple ordinary least squares estimates of the effect of interest rates on output growth are likely to be biased. However, central banks may pursue policy goals that are not directly related to output innovations. For example, countries often peg their currency to that of a base country to obtain credibility, stabilize financial markets, or reduce inflation. Some central banks even choose 'anchors' to their monetary policy whose explicit goal is to detach interventions from output stabilization. Alternative goals can provide additional estimation strategies that allow consistent estimation of at least partial effects of monetary policy on the real economy. 
Suppose the central bank sets monetary policy taking into account expected future inflation and output growth according to the reaction function

$$
i_{t}=\beta_{0}+\beta_{1} \hat{y}_{t \mid t-1}+\beta_{2} \hat{\pi}_{t+1 \mid t-1}+v_{t},
$$

where the interest rate $\left(i_{t}\right)$ is taken to be the central bank's main policy tool, $\hat{y}_{t \mid t-1}=$ $E\left[y_{t} \mid \Omega_{t-1}\right]$ and $\hat{\pi}_{t+1 \mid t-1}=E\left[\pi_{t+1} \mid \Omega_{t-1}\right]$ denote the monetary authority's forecast of real output growth and the lead of inflation based on information available as of date $t-1$ and assuming no change in stance, and $v_{t}$ is an orthogonal policy disturbance. Such a reaction function has been proposed by Richard Clarida and Gertler (2000) based on Taylor (n.d.), but a forward-looking component of monetary policy is implicit in many classic discussions of monetary policy (e.g., Bernanke and Blinder 1992, Bernanke and Mihov 1998, or Romer and Romer 1989). Equation (1) has also become integral part of recent theoretical models of monetary policy and the economy such as Engel and West (2004), Gali and Monacelli (2002), or Benigno (2004).

A common regression specification in the literature for a linear relationship between real output growth $\left(y_{t}\right)$ and the interest rate $\left(i_{t}\right)$ has been

$$
y_{t}=\alpha_{0}+\theta i_{t}+\phi_{1}^{\prime} W_{t-1}+u_{t}
$$

where $\theta$ represents the short run causal effect of interest rates on the real economy, and $W_{t-1}$ includes other variables such as inflation as well as lags of all variables in the system. The ordinary least squares estimator of $\theta$ will be consistent if conditional on $W_{t-1}$ the interest rate $i_{t}$ is uncorrelated to the error component, i.e., if

$$
C\left[u_{t}, i_{t} \mid W_{t-1}\right]=0
$$

Given the central bank's reaction function (1), it is clear this will only be the case if the variables at disposition to the researcher are sufficient for the central bank's information set. However, generally $W_{t-1}$ is likely to be a strict subset of $\Omega_{t-1}{ }^{3}$

\footnotetext{
${ }^{3}$ Another requirement for consistency is that the lag-structure of the model be specified correctly, see below.
} 
As discussed in detail below, Equation (2) corresponds to the output equation of a standard system of equations commonly estimated in the literature in a framework of vector autoregressions. In this context, a common approach to solve the problem of forward-looking bias has been to specify a rich enough set of lags within a system of equations containing the interest rate, output, and prices (e.g., Bernanke and Blinder 1992, Bernanke and Mihov 1998). Recently, Bernanke and Boivin (2004) and Bernanke et al. (2003) have further improved on this approach by allowing for an arbitrary number of observable covariates to enter a system of dynamic equations. Another version of this approach is Romer and Romer (2004), who estimate Equation (1) directly using the actual forecasts of output growth and inflation used by the U.S. Federal Reserve. Either of these approaches must maintain the orthogonality condition (3), and could thus be termed the 'conditioning approach.'

Most analysts do not "hang their hat" on the orthogonality condition (3), viewing it instead as an assumption which may be incorrect to a greater or lesser degree. This is undoubtedly because it is typically difficult to believe that the econometrician observes all information at the fingertips of the central bank. Even in the unusual case when the econometrician observes the actual forecasts of output growth and inflation used by the monetary authority, as in Romer and Romer (2004), it is probably true that monetary policymakers systematically downplay forecasts that seem out of line with conventional wisdom regarding the health of the economy or the future path of inflation, and systematically esteem forecasts that confirm such views. ${ }^{4}$

Because of these difficulties with the conditioning approach, it may be useful to consider a complementary approach based on instrumental variables, which may be termed a 'projection approach'. Instead of conditioning on 'all other' relevant factors, an instrumental variable approach in this context seeks to directly control the source of movements in the interest rate. Suppose for example that the central bank has goals that are uncorrelated with short

\footnotetext{
${ }^{4} \mathrm{An}$ econometric interpretation of this phenomenon is that the coefficients on the forecasts in Equation (1) are time-varying, whereas the econometrician estimates time-constant coefficients.
} 
run swings of the national economy. Such goals can provide an observable source of shocks to the interest rate that allow consistent estimation of the causal short run effect of monetary policy on output growth $\theta$. The basic idea behind this approach goes back to Friedman and Schwartz (1963) and Romer and Romer (1989) who sought to identify the effect of monetary policy on the real economy by finding situations in which the change in the stance of monetary policy was not only dictated by immediate economic circumstances. However, a more systematic use of this identification strategy has so far not been fully pursued in the literature. Our approach could be viewed as a formalization of what has been termed the 'narrative approach' into a dynamic regression framework. Since it also a straightforward extension of the basic VAR model, as shown in the next section, the instrumental variable approach can also be viewed as nesting the 'narrative' and VAR paradigms.

Concretely, consider the following specification of reaction functions for European central banks in the 1980s and 1990s,

$$
i_{t}=\beta_{0}+\beta_{1} \hat{y}_{t \mid t-1}+\beta_{2} \hat{\pi}_{t+1 \mid t-1}+\beta_{3} z_{t}+\nu_{t}
$$

where $z_{t}$ could be an exchange rate target or a foreign interest rate. If this additional target is uncorrelated with central banks' expectation of future output or inflation realizations, then it leads to changes in the interest rate that are uncorrelated with the disturbance in Equation (2). Instead of Condition (3) the orthogonality condition becomes $\operatorname{cov}\left[u_{t}, z_{t} \mid W_{t-1}\right]=0$, which is the required condition for the validity of an instrumental variables (IV) estimator. The system of equations corresponding to the IV estimate consists of Equation (2) and an equation for the interest rate. Using the policy reaction function (4), the so called 'first-stage' regression can be written as

$$
i_{t}=\beta_{0}+\phi_{2}^{\prime} W_{t-1}+\beta_{3} z_{t}+\eta_{t}
$$

where the error $\eta_{t}$ is the sum of $\nu_{t}$ and an error reflecting the differences in the information of the researcher and the central bank. If $z_{t}$ is uncorrelated with $u_{t}$, the error in Equation 
(2), then $z_{t}$ generates quasi-experimental variation in $i_{t}$ that allows for consistent estimation of the causal short run effect of nominal interest rates on the economy. In other words, two-stage least squares projects the national interest rate onto $z_{t}$ and thereby uses only the orthogonal variation in the interest rate for estimation. The main advantage of the 'projection' approach is that it will yield consistent estimates in the presence of forward looking policy decisions. In addition, by a direct comparison of IV and OLS estimates, it can be used to assess the size of the bias due to forward-looking policy decisions.

Before discussing our empirical application in more detail, it is instructive to briefly compare the IV approach to identification pursued in this paper to identification within 'classic' structural VAR models. Suppressing intercepts, a VAR comparable to the twoequation system used here can be written as

$$
\left(\begin{array}{cc}
1 & -\theta \\
0 & 1
\end{array}\right)\left(\begin{array}{l}
y_{t} \\
i_{t}
\end{array}\right)=\left(\begin{array}{l}
\phi_{1} \\
\phi_{2}
\end{array}\right) W_{t-1}+\left(\begin{array}{l}
\epsilon_{1 t} \\
\epsilon_{2 t}
\end{array}\right) .
$$

Identification within this system of equations is usually specified in terms of the matrix on the contemporaneous correlations alone, leaving the structure of lags completely flexible. ${ }^{5} \mathrm{~A}$ common identifying assumption is to exclude contemporaneous feedback of output growth on the interest rate (or of interest rates on output, which is equivalent in statistical terms), setting the lower left hand parameter of the matrix of contemporaneous correlations to zero. Comparing this to the preceding discussion, it is clear that this identification strategy is equivalent to imposing assumption (3) conditional on all of the lags of the system. ${ }^{6}$

Within the same system of equations, an IV estimator follows by specifying another equation and introducing an additional exclusion restriction. This exclusion restriction "frees up" the parameter on the contemporaneous correlation of output growth and interest rate

\footnotetext{
${ }^{5}$ In the earlier literature on VARs, identification of the effects was mainly based on the ordering of variables and a factorization of the error matrix to achieve a recursive system. In the case of structural VARs, restrictions on the matrix of contemporaneous correlations are determined by economic theories; the resulting system can but need not be recursive; see e.g., Bernanke (1986) or Blanchard and Watson (1986).

${ }^{6}$ In standard VAR analysis, this assumption means that the reduced form of the system may be estimated consistently by least squares. The structural disturbances are then obtained from the reduced form residuals by method-of-moments techniques. These in conjunction with the parameter estimates of the lag-structure are then used for further analysis.
} 
which is restricted to zero in the standard approach. The complete corresponding system of equations for IV is

$$
\left(\begin{array}{ccc}
1 & -\theta & 0 \\
\lambda & 1 & \beta \\
0 & 0 & 1
\end{array}\right)\left(\begin{array}{c}
y_{t} \\
i_{t} \\
z_{t}
\end{array}\right)=\left(\begin{array}{c}
\phi_{1} \\
\phi_{2} \\
\phi_{3}
\end{array}\right) W_{t-1}+\left(\begin{array}{c}
\epsilon_{1 t} \\
\epsilon_{2 t} \\
\epsilon_{3 t}
\end{array}\right)
$$

In this system of equations the restriction $\lambda=0$ is not needed for identification, implying that there can be contemporaneous correlation between interest rates and output growth, as for example induced by forward-looking monetary policy (not captured by pre-determined variables in the system). The identification strategy proposed in this paper thus leads to a non-recursive structural VAR that is less restrictive than the more common approach. ${ }^{7}$ In addition, we believe that the instrumental variable approach to identification can potentially help to make necessary identifying assumptions and their limitations more transparent. ${ }^{8}$

In our empirical application, we argue that the German central bank was the leader for monetary policy for many European countries indirectly since the break down of Bretton Woods, and directly since the conception of the European Monetary System (EMS) in 1979. As noted above, estimates of the degree of leadership differ in the literature (e.g., Giavazzi and Giovannini 1987, or von Hagen and Fratianni 1990). However, there is little disagreement with the assertion in terms of a general proposition. Richard Clarida and Gertler (1998) and

\footnotetext{
${ }^{7}$ For an in depth discussion of identification within reduced form, recursive, and structural VARs, and an explicit discussion of the IV system in the text, see Hamilton (1994).

${ }^{8}$ To see the relation of our approach to that used in Bernanke and Mihov directly, rewrite their model with a single lag:

$$
\begin{aligned}
& y_{t}=a_{0}+a_{1} i_{t}+a_{2} y_{t-1}+a_{3} i_{t-1}+\nu_{1 t} \\
& i_{t}=b_{0}+b_{1} y_{t}+b_{2} y_{t-1}+b_{3} i_{t-1}+\nu_{2 t} .
\end{aligned}
$$

Bernanke and Mihov focus on the case where $\nu_{2 t}$ is uncorrelated with future output realizations and $b_{1}=0$. (In fact, Bernanke and Mihov (1998) assume that there is no contemporaneous effect of interest rates on output. Both assumptions identify the model.) This corresponds to assuming that conditional on the recent history of the system, monetary policy is not forward-looking, and that there is no current effect of output on interest rates. Adapting our framework to their dynamic model suggests the estimation equations

$$
\begin{aligned}
& y_{t}=\alpha_{0}+\theta_{0} i_{t}+\theta_{1} i_{t-1}+\phi_{1}^{\prime} W_{t-1}+u_{t} \\
& i_{t}=\beta_{0}+\beta_{1} z_{t}+\beta_{2} z_{t-1}+\lambda i_{t-1}+\phi_{2}^{\prime} W_{t-1}+\eta_{t} .
\end{aligned}
$$

Since $W_{t-1}$ will typically contain lagged values of output, the main difference between the two models is the inclusion of current and lagged foreign interest rates in the policy equation.
} 
Clarida and Gertler (1997) describe how the Bundesbank's reaction function is similar to that of the Federal Reserve, and can be well described by Equation (1). They find a statistically significant but economically small role for the US-DM exchange rate. On the other hand, Richard Clarida and Gertler (1998) show that the German interest rate plays an important role in the reaction function of France, Italy, and the UK. ${ }^{9}$ Based on these considerations, we use the German interest rate as an instrument for the nominal rate of other European countries and provide explicit estimates of relationship (5).

That countries constrain the scope of their domestic monetary policy also receives empirical support from recent work by Shambaugh (2004) and Obstfeld, Shambaugh and Taylor (2004a,b) who show that the co-movement of interest rate changes is higher under pegged exchange rates than under floating rates. Their approach is similar to ours in that they also try to estimate the correlation between countries' interest rates to that of a base country. We specify our first-stage equation in levels since our identification strategy does not allow for the inclusion of lagged endogenous variables (see below). Invoking uncovered interest rate parity, these authors argue that estimating interest relationships in levels is inappropriate if interest rates of the base country are highly persistent. This is less likely to be a problem in our application, since for part of the period capital controls were in place and the time horizon we consider is relatively short. In addition, it can be shown that a regression in levels is again appropriate if central banks' behavior can be described by a reaction function of the type (4). ${ }^{10}$ We also argue in the Appendix that for the countries and period we consider, our first-stage relationship could be interpreted as a co-integrating relationship. Thus, we treat the level-relationship we uncover as a robust feature of the data. ${ }^{11}$

\footnotetext{
${ }^{9}$ The authors do not analyze the role of European exchange rates in the Bundesbank's reaction function, nor do they explicitly compare the role of exchange rates vs. interest rates in the other countries' functions.

${ }^{10}$ If only uncovered interest rate parity holds and interest rates follow a unit root, a regression of home interest rate on base country interest rate in levels would bias the coefficient estimates towards unity since the variance in the base interest rate swamps that of exchange rate expectations in the limit. However, it is easy to show that the same regression uncovers the true coefficient on the base country's interest rate in equation (4). Uncovered interest parity need not have held in the period we consider due to partial capital controls.

${ }^{11}$ Note that it is controversial whether interest rates should follow a random walk and whether they actually
} 
Since European economies are closely linked by trade flows and financial markets, output and inflation innovations are likely to be correlated across countries (Frankel and Rose 1998). This will lead IV estimates to have a remaining bias. In our empirical application, we will include lags of domestic output growth and inflation to absorb sources of co-movement in interest rates due to economic factors. However, it is likely that in a macroeconomic context it will be hard to absorb all sources of correlation across countries. An advantage of our approach is that the bias can be readily expressed in terms of interpretable and potentially estimable parameters.

Let $\eta$ be the coefficient on German output growth innovations in the population regression of home country output growth innovations on German innovations. Then the bias of the IV estimator can be approximated as

$$
B_{I V} \approx \frac{\eta}{\beta_{3}} B_{O L S}^{*}
$$

where $B_{O L S}^{*}$ is the forward-looking bias of German monetary policy, and $\beta_{3}$ is the regression coefficient on the German interest rate in the 'first-stage' Equation (5). Thus, the approximate bias of IV increases with the correlation of output shocks and the degree to which the Bundesbank is forward-looking in its monetary policy choices, and decreases with the strength of the correlation of national and German interest rates. As shown in the Appendix, IV has smaller approximate bias than OLS if

$$
\eta<\beta_{3} /\left(1-\rho^{2}\right)
$$

where $\rho$ is the conditional correlation of domestic and foreign interest rates. As we show below, $\beta_{3}$ is close to 0.8 and $\rho$ is close to 0.4 , leading the right hand side of (9) to be over 0.95. ${ }^{12}$ Because output shocks are unlikely to be correlated more than moderately, this leads to a fairly firm prior that IV estimates will be less biased than OLS, and our empirical work below buttresses this conviction.

do. Moreover, unit root tests are known to have low power in short time series. With this caveat in mind, the unit-root and cointegration tests in the Appendix show that in cases in which interest rates follow a unit root they are usually cointegrated with Germany's interest rate.

${ }^{12}$ Clearly both $\beta_{3}$ and $\rho$ will vary by country; we refer to pooled estimates of their magnitudes. 
Since the difference in IV and OLS estimates is equal to the difference in the biases, we can use Equation (8) to relate the relative bias to countries' macroeconomic relationships with Germany. For example, if a country is heavily dependent on trade with Germany (relative to its GDP), then shocks that hit Germany will be directly transmitted to the domestic economy as German supply and demand for goods adjust. In this case, forward looking monetary choices by the Bundesbank will be correlated with a country's GDP growth, making it more difficult to differentiate between the OLS and IV estimates. ${ }^{13}$ Factors governing the degree of a country's monetary independence also determine the relative bias between IV and OLS. For example, the wider exchange rate bands in target zone, the more can domestic interest rates temporarily deviate from those of the base country. If larger "effective" exchange rate bands imply higher exchange rate volatility, we expect the size of the OLS-IV difference (IV estimate) to be positively related to volatility.

Another practical issue that we have to address in the case of open economies is that real exchange rate changes may lead to both an increase in interest rates as well as improvement in competitiveness. For example, if the Bundesbank lowers interest rates in response to a worsening of the German terms of trade (which it is known to have done, see Clarida and Gertler 1997) and if the French terms of trade were simultaneously improving, then our instrument may itself suffer from omitted variable bias. We have therefore tried to include lags of the real exchange rates as additional controls in our models. The results were basically unchanged. ${ }^{14}$

An apparent drawback of the proposed approach is that $\theta$ is a measure of the short run causal effect of a change in interest rates on economic growth. Typically, $W_{t-1}$ contains several lags of the interest rate, and researchers have been interested in the entire dynamic path of the effect of interest rate shocks. To relate our short term estimates to the more

\footnotetext{
${ }^{13}$ Another measure of similarity between countries is bilateral distance. Thus, one would expect that the size of the IV estimator and of the OLS-IV difference to be increasing with distance.

${ }^{14}$ Note that we do not want to control for the transmission of interest rate changes through the real exchange rate. Similarly, the current real exchange rate might be an outcome variable in itself. Therefore we do not include the contemporaneous real exchange rate as a control variable.
} 
conventional ones from the literature, suppose that in place of (2) the data-generating process is

$$
y_{t}=\alpha_{0}+\theta_{0} i_{t}+\theta_{1} i_{t-1}+\ldots+\theta_{p} i_{t-p}+\phi_{1}^{\prime} W_{t-1}+u_{t} .
$$

Then a straightforward omitted variable calculation shows that the probability limits are

$$
\begin{aligned}
& \hat{\theta}_{O L S} \stackrel{p}{=} \theta_{0}+\theta_{1} \gamma_{1}+\theta_{2} \gamma_{2}+\ldots+\theta_{p} \gamma_{p}+\frac{\beta_{3} C\left[z_{t}, u_{t} \mid W_{t-1}\right]+C\left[\eta_{t}, u_{t} \mid W_{t-1}\right]}{V\left[i_{t} \mid W_{t-1}\right]} \\
& \hat{\theta}_{I V} \stackrel{p}{=} \theta_{0}+\theta_{1} \gamma_{1}^{I V}+\theta_{2} \gamma_{2}^{I V}+\ldots+\theta_{p} \gamma_{p}^{I V}+\frac{C\left[z_{t}, u_{t} \mid W_{t-1}\right]}{C\left[z_{t}, i_{t} \mid W_{t-1}\right]}
\end{aligned}
$$

where $\gamma_{j}=C\left[i_{t}, i_{t-j} \mid W_{t-1}\right] / V\left[i_{t} \mid W_{t-1}\right], j=1,2, \ldots, p$ are the autocovariances of interest rates, and $\gamma_{j}^{I V}=C\left[z_{t}, i_{t-j} \mid W_{t-1}\right] / C\left[z_{t}, i_{t} \mid W_{t-1}\right]$ are the instrumental variable analogues.

Consider briefly the interpretation of the summary parameter $\theta \equiv \theta_{0}+\theta_{1} \gamma_{1}+\ldots+\theta_{p} \gamma_{p}$. The parameter summarizes (i) the instantaneous effect of monetary policy on the real economy, $\theta_{0}$, and (ii) the historical effect of monetary policy on the real economy, or $\theta_{j}$ for $j=1,2, \ldots p$. The weight $\gamma_{j}$ applied to the historical influence of monetary policy has a natural interpretation - it measures the extent to which a monetary tightening in period $t$ predicts that monetary policy was tight in period $t-j$. In short, the summary parameter $\theta$ measures the general effect of an episode of tight monetary policy of a given magnitude. Thus, while our approach does not allow us to trace out the entire dynamic effect of monetary policy on the real economy, it does allow us to identify a parameter of interest to policymakers.

However, OLS does not identify the summary parameter $\theta$ due to the bias term in Equation (10). It is therefore of interest to note that IV does identify the parameter of interest (when $C\left[z_{t}, u_{t} \mid W_{t-1}\right]=0$ ). This follows because the implicit OLS and IV weighting functions are (under a mild assumption) equal: $\gamma_{j}=\gamma_{j}^{I V} .{ }^{15}$ That is, abstracting from issues of bias attributable to forward looking monetary policy (OLS) and co-movements of output

\footnotetext{
${ }^{15}$ This follows immediately from a few lines of algebra. Linearly project the German interest rate onto the national interest rate for period $t$, and plug these linear projections into the definition of $\gamma_{j}^{I V}$. The "mild assumption" mentioned holds that the residual from this projection is orthogonal to lagged home country interest rates, which we view as innocuous since the projection residual is by definition orthogonal to current home country interest rates.
} 
shocks (IV), the OLS and IV estimators manage to identify the same parameter of economic interest. Thus, in an environment where monetary policy affects the economy with a lag, estimation of a static model such as ours combines the current effect of monetary policy with a weighted sum of the effects of past policy. This reasoning leads us to view our static estimates as identifying a reduced form parameter summarizing the stance of the monetary authority during a general tightening.

If we treat the lag of interest rates as predetermined, a simple dynamic extension of our IV approach would amount to using $z_{t-1}$ as an additional instrument for $i_{t}$. An alternative would be to treat both $i_{t}$ and $i_{t-1}$ as endogenous and to instrument them by $z_{t}$ and $z_{t-1}$. However, interest rates tend to be highly persistent. While this is also a problem for identification in standard vector autoregression models that include multiple lags of the interest rate, it is a particular problem for IV estimation. Essentially, current and lagged foreign interest rates do not provide enough distinct variation to function as two separate instruments. Thus, in the empirical section we limit ourselves to discussing some estimates for the case in which $i_{t-1}$ is treated as predetermined in the sensitivity analysis.

\section{Data and empirical results}

\subsection{Data and empirical implementation}

We estimate OLS and IV regressions of the impact of nominal short term interest rates on real output growth for eleven European countries using quarterly data from 1973 to 1998. These countries are chosen given data availability and include but are not limited to most participants in the European Monetary System (EMS): The countries are Austria, Belgium, France, Great Britain, France, Italy, Netherlands, Norway, Portugal, Spain, Sweden, and Switzerland. ${ }^{16}$ Nominal GDP data are taken from the International Monetary Fund's International Financial Statistics (IFS) database and are deflated by each country's real GDP deflator $(1995=100$, also from the IFS database). To control for seasonal components we

\footnotetext{
${ }^{16}$ Notable exceptions due to data limitations on quarterly nominal interest rates are Denmark and Ireland.
} 
include quarterly dummies in all specifications. We lack complete data for quarterly GDP for Belgium, Italy, the Netherlands, Portugal, and Sweden in the 1970s. ${ }^{17}$ The short-term interest rate by which we measure monetary policy is the overnight lending or call money rate from the Global Financial Database. We average end-of-month rates quarterly. ${ }^{18}$ We also have tried using the central bank's discount rate, and the three month T-bill rate (annualized). Our results are generally robust to the choice of interest rates used.

The main estimation equations are (2) and (5), where the level of the quarterly German overnight rate is used as an instrument for the level of the call money rate in the other European countries. It is widely accepted in the literature that the German central bank became the effective trend-setter in the stance of monetary policy for other European countries since the break down of the Bretton-Woods system. This role of leadership was strengthened within the EMS founded in $1979,{ }^{19}$ and a large literature grew out of the attempt to quantify and explain the degree of the ensuing asymmetry. ${ }^{20}$ Some have argued that Germany effectively ran monetary policy for the entire EMS (e.g., Giavazzi and Giovannini 1987); others have argued that German dominance left room for own monetary policy action as intended by the founders of the EMS (e.g., von Hagen and Fratianni 1990). Thus, while German monetary policy seems to have been a strong influence on countries' interest rates, this did not negate forward-looking behavior on the part of the monetary policy, particularly for larger countries within the EMS, and those who joined late or had wider exchange rate bands. For

\footnotetext{
${ }^{17}$ Data are missing from 1973Q1-1980Q2 (Belgium), 1973Q1-1977Q1 (Netherlands), 1973Q1-1977Q1 (Portugal), and 1973Q1-1980Q1 (Sweden). For Portugal we are also missing interest rate data from 1973Q11975Q3.

${ }^{18}$ Overnight/call money rates are missing for two countries: 1973Q1-1978Q2 (Italy) and 1973Q1-1975Q3 (Portugal).

${ }^{19}$ This system was precluded by an informal joint float against the dollar known as the "snake". Members of this system were Belgium, Germany, Luxembourg, and the Netherlands. France, Great Britain and Italy participated briefly and sporadically in the snake during the 1970s.

${ }^{20}$ The original members of the EMS (and their initial exchange rate bands) in 1979Q1 were Belgium $( \pm 2.25 \%$, Denmark $( \pm 2.25 \%)$, France $( \pm 2.25 \%)$, Germany $( \pm 2.25 \%)$, Ireland $( \pm 2.25 \%)$, Italy $( \pm 6 \%)$, Luxembourg (1979Q2, $\pm 2.25 \%)$, the Netherlands $( \pm 2.25 \%)$. Late joiners included Great Britain (1990Q1, $\pm 6 \%$ ), Portugal (1992Q1, $\pm 6 \%$ ), and Spain (1990Q1, $\pm 6 \%$ ). Note that the exchange rate band expanded, for all countries remaining in the EMS, to $\pm 15 \%$ in 1993Q3. See Table A3 for more details on the realignments over time.
} 
the smaller, open countries on the other hand, pegged exchange rates and flexible capital markets may have left little scope for independent monetary policy. ${ }^{21}$ This may have made a difference for countries whose output shocks correlated closely with those of Germany. After presenting the basic results we will address these predictions directly.

\subsection{Main Empirical results}

We first present results for a simple baseline model with no additional covariates included. Table 1 contains results for a regression of real quarterly output growth on nominal interest rates for all countries, sorted by GDP. The baseline specification is only correct under the stylized case in which the central bank controls the interest rate directly, and has as its only objective the smoothing of output. In this special case, the interest rate is only a function of the central bank's projection of shocks that are unexpected by the market (thus, interest rates should be orthogonal to any market information). Clearly, the interest rate is in effect also determined by market forces as well as by other policy goals of the central bank. For example, if the central bank uses the interest rate to manage inflation, and lagged inflation correlates positively with output growth, then the coefficient on nominal interest rates in a growth regression might understate the effects of monetary policy. Additional covariates also help to partially control for forward-looking behavior of the central bank and thereby reduce the potential bias of OLS estimates. Therefore, Table 1 also adds four lags of real output growth and inflation to our baseline specification. (Table 2 and 3 present further regression specifications for models that pools multiple countries.) All tables report two sets of standard errors; usual heteroscedasticity robust Eicker-White standard errors are in parentheses, and Newey-West standard errors correcting for 4th order serial correlation are in squared brackets. The two sets of standard errors are quite similar, and the choice of

\footnotetext{
${ }^{21}$ The existence of flexible capital markets was not always the case during the EMS-period. As Giavazzi and Giovannini (1989) point out, the use of capital controls were predominant in many of the "weaker" currency countries. Paradoxically, Giavazzi and Giovannini find that though these controls had a tendency to break the link between interest rates (as measured by the differential in movements of on-shore and offshore rates), they could not reject France and Italy's monetary policy from being different from Germany's during the period.
} 
standard error affects our results only for very few cases. Neither seems to be overall more conservative, so we chose to report both.

Basic OLS estimates of the effect of monetary policy are shown in Column (1) of Table 1. Taken at face value, these estimates imply that a one percentage point increase in the interest rate lowers quarterly real growth only moderately: 0.094 percentage points in the Netherlands and only 0.015 percentage points in France. The average effect across countries is -.043 , the median is -.039 . To summarize the basic relationship across countries, and help to assess the impact of different specifications on the overall effect of monetary policy, we also pool our results using several alternative variables as weights. The pooled OLS estimates are shown in Table 2. Specifically, pooled estimates are presented in which countries are equally weighted [Pooled 1] and weighted by (i) GDP in 2003 US Dollars [Pooled 2], (ii) the fraction of their GDP not due to trade [Pooled 3], and (iii) the volatility of their exchange rate vis-a-vis the German Mark [Pooled 4]. ${ }^{22}$ The pooled estimates also help to assess to what extent our results are common across countries or driven by outliers. We do not view them as an estimate of a common underlying parameter, but rather as a summary measure of the individual coefficients. ${ }^{23}$ However, in calculating the pooled estimates, we restrict the first stage and reduced form coefficients to be equal across countries for computational reasons. ${ }^{24}$ The average effect for the pooled OLS results without control variables in Row (A) of Table 2 is -0.031 percentage points, where the equally weighted [Pooled 1] yields the most negative OLS estimates with -.0325.

The corresponding estimates using the German interest rate as an instrument for the

\footnotetext{
${ }^{22}$ See Appendix Table A1 for the weights used for these regressions as well as other summary statistics.

${ }^{23}$ In the case of fixed country-specific weights, one can show that the pooled estimates are a weighted function of the country-specific coefficients (with weights proportional to the fixed country-weight in the pooled model).

${ }^{24}$ It would seem sensible to allow country-specific first-stage coefficients to reflect differences in the underlying mechanism across countries. However, doing so we face a problem of multiple weak instruments very similar to that faced by Angrist and Krueger (1991), who also interact their instrument with state-dummies. As discussed in the ensuing literature on weak instrument, this risks 'over-fitting' the first-stage relationship and biases IV results towards OLS. However, our pooled estimates are remarkably similar to the sum of the separate estimates weighted by the inverse of their variances (the optimal method-of-moments estimator under the hypothesis of a common coefficient), suggesting to us that this limitation may not be severe.
} 
national interest rate are shown in Column (3) of Table 1. For all countries (except Austria and Belgium), the IV estimates are more negative than the OLS estimates. This suggests that some degree of endogeneity with respect to real output growth affects most countries' interest rates. A simple interpretation of this endogeneity is that it is capturing the extent to which the monetary authority is forward-looking. The pooled IV estimates in Row (A) of Table 3 summarize this result: the IV estimate suggests that a one percentage point increase in interest rates (on average) causes a reduction in real output growth of 0.113 percentage points, which exceeds the OLS estimate by a factor of three. Column (2) also shows the only case for which choice of standard errors makes a sizeable difference for significance levels Spain. The differences between OLS and IV is always statistically significant in the pooled models. For single countries, the difference between OLS and IV is shown in Columns (3) and (6) of Table 1. It is generally significant and larger for bigger countries (e.g., Great Britain, France, Italy, and Spain), as expected and further discussed below. ${ }^{25}$

To the extent that the central bank pursues other policies or is forward-looking, the results of the baseline model without other regressors might be affected by a bias from confounders affecting both nominal interest rates and real output growth. As discussed in Section 2, above, natural control variables are lags of growth itself: for example, if lagged growth positively affects current growth rates and is positively correlated with current interest rates, then the baseline results may understate the effect of monetary policy. Similary, if lagged inflation rates capture some of the effect of lagged interest rates on output growth, they may reduce the negative effect of current interest rates. As frequently exploited in the literature, covariates may also help to reduce the bias from forward-looking monetary policy. They should thereby yield more negative OLS estimates, and reduce the difference between OLS and IV.

\footnotetext{
${ }^{25}$ The standard errors in Columns (3) and (6) of Tables 1 and 6 are computed as square root of the differences in variance of IV and OLS estimates. Note that in the case of heteroscedasticity-robust or Newey-West standard errors, this is only an approximation, since the covariance of the coefficients is not equal to the simple differences in the variances.
} 
The results including the first four lags of real output growth and inflation are shown in Columns (4) to (6) of Table 1. Compared to the baseline models in Columns (1) to (3), the more extended specifications show only small differences in OLS estimates, suggesting that past output growth and inflation rates are not strongly correlated with current interest rates or output growth. The differences between the OLS results are never significant, nor do they appear to follow a particular pattern across countries. However, there are some minor differences in the IV estimates; in particular, it appears that inclusion of lags of output growth on average strengthens moderately the estimated IV effect for all countries but Spain and Austria. Note that some heterogeneity in coefficient estimates is to be expected due to sampling variation alone. Thus, we do not put too much weight on occasional or obvious outliers.

Table 2 and Table 3 show a wide range of additional specifications for models pooling all countries using different weights. Since the choice of lags in time series regressions is somewhat arbitrary, we choose to report several specifications for alternative weighting schemes. Rows (B) to (G) vary the combinations of lags of inflation and output growth included in the pooled regression. In so doing, it is possible to allow coefficients other than that on the interest rate to vary by country - for example, the first lag of inflation may be entered separately for each country, while the effect of the interest rate may be constrained to be the same across countries. Rows (H) and (I) allow for different lag coefficients for each country. A quick glance at the table indicates that this additional flexibility of the specification affects the interest rate estimate in only very minor ways. To summarize the information in the table, the last rows also report the mean, median, and standard deviation of an extended set of regression specifications (including additional country-specific lags of variable order for inflation and output growth). In all specifications IV remains more negative than OLS. The effects in Row (A) of Table 3 indicate a reduction in real growth (averaged over the four pooled estimates) of 0.115 percentage points, but the average effects in Row $(G)$ indicate a reduction of 0.15 percentage points would be expected. Overall, if covariates were able to 
control for the bias arising from forward-looking monetary policy, we would have expected that OLS becomes more negative, and that the difference between OLS and IV declines. Our results suggest the opposite.

Our IV estimates are based on a strong and significant 'first-stage' relationship between national and German interest rates underlying the IV estimates (Table 4). This is the fundamental relationship providing us with quasi-experimental variation in interest rates. Most countries have a first-stage coefficient of at least .8. However, several countries, including Great Britain, Spain, and Switzerland have first-stage coefficients on the German interest rate significantly below unity. Moreover, Norway, Spain, and Sweden's coefficients are between .5 and .6. Thus, it does not appear that our first-stage relationship is systematically biased towards unity. ${ }^{26}$ Not surprisingly, some of the countries with low first-stage coefficients either were never part of the EMS or joined late. The remaining columns of Table 4 again include up to four lags of output growth and inflation. Additional variables control for co-movements in interest rates driven by common pattern of output shocks and inflation. On average, including lags of inflation and output growth reduces the first-stage coefficient. Lags of output growth tend to increase the first-stage coefficient, while lags of inflation tend to reduce it. This would be expected if lagged inflation partially captures the influence of past interest rates. However, for most countries the differences are not significant. The exceptions are Great Britain, Italy, and Sweden, neither of which we would have thought to be particularly correlated with the German economy. To directly assess the affects of changes in specifications, Table 5 summarizes a wide variety of different specifications for first-stage regression models pooling all countries with alternative weights. The largest pooled estimate

\footnotetext{
${ }^{26}$ Given the range of estimated coefficients, some significantly below unity, the limited time range, and the partial presence of capital controls during the period of study we do not believe we are subject to the critique raised by Shambaugh (2004) discussed in Section 1. However, we ran several tests for nonstationarity in interest rates and cointegration which are summarized in Appendix Table 4. Overall, although we do not find that interest rates have unambiguous stochastic trends, for some specifications we cannot reject a unit root. However, for those countries we also find that the interest rate exhibits a cointegrating relationship with Germany. For example this can be seen for Great Britain, the Netherlands, or Austria in the case of the standard Dickey-Fuller test for specifications with four lags of output growth and inflation as control variables.
} 
is .91, the smallest is .69, and most pooled first-stage coefficients are between .75 and .8. We conclude that German monetary policy appears to be a strong and robust determinant of interest rates for the countries included in our sample.

To summarize the differences in IV estimates we explore the relationship between our IV estimates and proxies for the approximate bias (cf. Equation (8)). A simple way to represent the relationship between these estimates and the relevant fundamentals suggested by Equation (8) is shown in Figure 1, which is based on the results from Table 1. Figure 1(a) plots the relationship between the IV estimates and the fraction of GDP due to trade with Germany. As predicted, the IV estimates become less negative the more important a country's trade with Germany is relative to its total output. ${ }^{27}$ Taken at face value, the relationship suggests that a country with no economic ties to Germany - or in other words, the "ideal" country in terms of the assumptions undergirding our identification strategywould have an IV coefficient of roughly -0.15. Figure 1(b) shows how IV estimates are more negative for countries whose currencies were more volatile viz. the German Mark. This result confirms the intuition that a more flexible exchange rate regime allowed countries more monetary independence. Hence the use of the German rate as an instrument picks up more exogenous monetary shocks in the domestic country.

The differences across countries carry over to the gap between OLS and IV estimates. The OLS-IV differences, shown in the third and sixth columns of Table 1, are positive and greater for larger countries. Based on the foregoing, we would also expect it to be larger for countries that are farther from Germany, are less dependent on trade with Germany, and have a more volatile exchange rate. This is shown in Figure 1(c) and 1(d). Although the cross-country heterogeneity in the OLS-IV difference is greater than that of the IV estimates, the correlations are as expected. The difference is (i) increasing with distance

\footnotetext{
${ }^{27}$ We also experimented using distance to Germany as a proxy for the amount of trade. The IV estimates (the difference between OLS and IV) become more negative (more positive) with distance, as expected, but the relationship is weaker. Given that distance is an imperfect measure of economic integration, we prefer the trade to GDP ratio as proxy for the similarity of output shocks.
} 
(not shown), (ii) decreasing with the trade to GDP ratio [Fig. 1(c)], and (iii) increasing with exchange rate volatility [Fig. $1(\mathrm{~d})] .{ }^{28}$ These correlations confirm the predictions of our simple representation of monetary policy decisions summarized in Equation (8), and suggest the gap between IV and OLS reflects at least partially the degree of endogeneity in monetary policy. However, in contrast to the results in Figure 1, there do not appear to be systematic differences between countries in the covariance of home country interest rates with the German interest rate viz. trade to GDP ratio or exchange rate volatility. Note that we would not have necessarily expected any systematic difference, since countries who had the option for more independence may still have an incentive to tie themselves to the German rate for other reasons (e.g., to foster convergence in the process of European integration).

We draw two main conclusions from the results presented in Tables 1 to 5. First, the differences between the OLS and IV estimates are large and systematic across countries, indicating that there may be a substantial component of monetary policy that is forwardlooking. Inclusion of lags of output growth and inflation does not appear to help to account for information differentials between central banks and the public. Second, the differences between OLS and IV appears to be an informative measure of the degree of endogeneity in monetary policy as suggested by the simple model of forward-looking monetary policy outlined in the first section. This suggests IV estimates are less biased than OLS estimates the less economically integrated a country is Germany (e.g., as measured by direct trade links), and the more flexible is its exchange rate regime vis-a-vis the German Mark. These correlations reinforce our view that the gap between OLS and IV estimates can be interpreted as evidence for the potential scope of endogeneity of monetary policy.

On average, OLS suggests that a 5 percentage point increase in nominal interest rates leads to decline in annual real GDP growth of 0.5 to 1 percentage points. Using German

\footnotetext{
${ }^{28}$ Again, the relationship with distance is not overwhelmingly strong, though this is in part driven by Great Britain (GBR), which is quite close to Germany as measured.
} 
interest rates as an instrument, the effect rises to 2 to 3 percentage points, a threefold increase. These results are robust to a wide range of specification checks, and are systematic across countries as suggested by a variety of weighting procedures.

A corollary to these findings is that larger countries should exhibit a greater inflationary bias since they were generally less dependent on Germany economically and had more discretion viz. their exchange rate regime. This prediction is borne out by the results of Table 1, with the exception of a small bias in France (which has followed German monetary policy quite closely specially during the EMS), and large biases in Norway and Switzerland. Given the large number of estimates we present these may partly represent outliers due to sampling variation. Overall, the results are consistent with the belief that smaller open countries may have less scope to conduct independent monetary policy. ${ }^{29}$

\subsection{Sensitivity Analysis: EMS-Period, Outliers, Dynamics}

The European Monetary System came into effect in 1979 and committed countries to keep their exchange rates within bands of the German rate. This should have increased the role of leadership of the Bundesbank, and further constrained the monetary policy actions of member countries. This strengthened the mechanism we exploit in our identification strategy, and thus it is important to see whether the results are confirmed in the EMS-period. On the one hand, by further constraining countries' monetary policy choices, we expect EMS to have led to more negative OLS estimates of the effect of interest rates on growth. On the other hand, von Hagen and Fratianni (1990) speculate that the Bundesbank itself may have become more lenient on inflation, since inflation's negative consequences for the German economy would be partially exported to the other countries under fixed exchange rates. This would imply lower IV estimates, since German monetary policy may have become more endogenous.

\footnotetext{
${ }^{29}$ For larger countries, the option for discretionary policy may lead to an inflationary bias. Thus, they should face a greater interest in binding themselves to the stricter monetary regime of the German central bank. This is beyond the scope of this paper.
} 
Table 6 shows the baseline regression for the EMS era (that is, 1979 to the present). Overall, the results strongly confirm those of Table 1; with or without lags of growth and inflation IV estimates are systematically more negative than OLS estimates, and more so for larger countries. The differences between the EMS period and the full sample are small but as expected. Most countries experience a small increase in the magnitude of OLS coefficients with the exception of Austria and the UK (for the specification with lags). Similarly, most countries see a slight reduction in the size of IV estimates with the exception of the UK. The pooled estimates (not shown) summarize this result. They show an increase in the OLS estimate of the effect of interest rates on growth from -.03 to -.0413 percentage points for constant GDP weights (the change is not statistically significant). Conversely, the pooled IV estimates display a decline in magnitude from -.1209 to -.0939. ${ }^{30}$ These changes are consistent with the hypothesis that monetary policy has become less endogenous in the follower countries and more endogenous in Germany since 1979. This is confirmed by a separate OLS regression for Germany. The coefficient on German nominal interest rate in a regression of quarterly growth rates of GDP drops from -0.073 to -.036, or from -.064 to zero when lags are included (although standard errors are again large).

The first-stage coefficients for most countries and for the pooled specifications (not shown) also tend to reflect the impact of the EMS. There has been an increase in the effect of German interest rates for several countries in our sample. For example Austria's coefficient is no longer significantly different from one, which is not surprising given that Austria effectively surrendered its monetary policy making decisions to Germany during the EMS. Similarly, we see increases for Italy and Spain, as would be expected, but also for the Netherlands. Only the UK has a smaller first-stage coefficient for some specifications. The coefficients from the pooled specifications increase on average from about .85 (see Row (A) in Table 5) to about 1 without control variables, and from about .7 (see Row $(\mathrm{G})$ in Table 5) to .82 for a more

\footnotetext{
${ }^{30}$ Including four lags of growth and inflation, the results are -.0346 vs. -.0203 for OLS and -.1353 vs. .10 for IV.
} 
conservative specification. The role of observable characteristics indicate that the increases are partly driven by convergence in growth and inflation. However, the main conclusion is robust to lags of output growth and inflation as controls. Thus, at least part of the increase in the first-stage relationships is a genuine policy change.

As noted in Section 2, above, estimates for the static model of equations (2) and (5) are a reduced-form parameter for the stance of monetary policy over the recent past. Specifically, if there are lagged effects of nominal interest rates on output growth, the results in Tables 1, 2, 3, and 6 can be interpreted as the weighted sum of the impact of current and lagged interest rates (see equations (10) and (11)). ${ }^{31}$ The differences in the point estimates across countries could thus be partly explained by the accumulation of differential effects over time and differences in the persistence of interest rates.

As a check on our results, we also ran a dynamic specification including lagged home country interest rates, assuming that lagged interest rates are predetermined. This assumption is tenuous, and would be violated if the central bank were able to accurately estimate output growth more than one period ahead. However, if the assumption were true and if past interest rates had a negative effect on output growth and a positive effect on current interest rates, we would expect inclusion of lagged interest rates to lower the coefficient on current interest rates both in OLS and IV regressions.

The data cannot identify effects for single countries with any degree of precision. For the pooled specifications, we find that inclusion of lagged interest rates (one or four lags) leads to differences in OLS estimates of unclear sign - if all countries are included OLS is more negative, but if only countries with complete data are included, it is less negative. In the first-stage, inclusion of lagged own interest rates reduces the coefficient on the instrument considerably, consistent with a positive correlation of current and lagged interest rates within and across countries. However, IV estimates turn these results upside down - including lagged interest rates leads to significantly positive effects of past interest rates on output

\footnotetext{
${ }^{31}$ Remember that the weights in the IV and OLS estimators can be shown to be identical.
} 
growth with stronger negative effects of current rates. This suggests that lagged interest rates may be endogenous as well, consistent with monetary policy actions with a horizon of several quarters. Unfortunately, as suggested in Section 2, the lags of German interest rates are too persistent to provide separate instruments for lags of followers' interest rates, and thus we cannot move beyond this point.

We also conduct some robustness checks. Figures A1 and A2 present leverage plots for each country for regressions with no output growth lags. The leverage is calculated as follows. We re-run the OLS and IV regressions, dropping an observation each period. We record the estimated interest rate coefficient, and then subtract the estimated interest rate coefficient from regressions using the whole sample (in this case, the estimates from Table 1). This is done for each period, so a point on the figure corresponds to the period where the data point has been dropped. The smaller the leverage the better. In examining the plots, the leverage coefficients are generally close to zero for most countries. Austria, the Netherlands and Sweden are exceptions. Not surprisingly, for these countries the OLS-IV difference is not significantly different from zero.

\section{Conclusion}

We have presented a sequence of simple estimates of the effect of monetary policy on real output growth, ranging from least squares contrasts to instrumental variables estimates. The identification strategy we have pursued attempts to exploit the fact that monetary policymakers may sometimes have competing goals. In particular, since the breakdown of the Bretton-Woods system, many European central banks have followed the leadership of the Bundesbank in setting monetary policy to stabilize their exchange and inflation rates. Using quarterly German nominal interest rates as an instrument for other European countries' nominal interest rates, we estimate that the causal effect of a 5 percentage point increase in nominal interest rates is a contraction in annual real growth of 2 to 3 percentage points. This is in contrast to naïve OLS estimates, which suggest a more modest contraction of 0.5 
to 1 percentage points.

The difference between OLS and IV estimates may be interpreted as a measure of the extent to which the monetary authority is forward-looking. An advantage of our approach is that we can use this difference to directly test for the presence of bias in simple estimates. We find a systematic and positive bias unaffected by the inclusion of lagged values of GDP growth or inflation as control variables. Moreover, we can relate the size of the bias to economic conditions affecting monetary policy. First, we show that the difference is decreasing with respect to the economic closeness between a country and Germany, as measured by physical distance and trade with Germany. Second, we show that the difference is increasing with exchange rate volatility vis-a-vis the German Mark. Finally, we find that during the period of pegged exchange rates under the European Monetary System, IV estimates of the effect of monetary policy, as well as the OLS-IV difference, are smaller than during the post-1973 period as a whole.

We believe the direct focus of IV on exogenous variations in interest rates and the transparency of the identifying assumptions underlying the IV estimates have the potential to generate substantial insight into the relationship between monetary policy and the real economy. We formalize the main idea of the identification strategy underpinning Friedman and Schwartz (1963) and Romer and Romer (1989) within a dynamic system of equations, thereby providing useful insights for the standard VAR approach as well. However, it is also clear that such an approach is not without drawbacks - for example, it does not appear practicable to tailor our approach to estimation of the dynamic impacts of policy. Moreover, clearly the applicability of our approach hinges on the presence of appropriate instruments. However, we view it as a potentially useful diagnostic and research tool in macroeconomic settings. 


\section{Appendix A The Bias of OLS and IV with Imperfect Instruments}

In a macroeconomic setting, the claim that $C\left[z_{t}, u_{t} \mid W_{t-1}\right]=0$ is probably overly strong since output shocks are likely to be correlated between countries. When the Bundesbank tightens, it is because they believe output growth exceeds potential growth. If this is likely to be occurring simultaneously in both the home country and Germany, then we might expect $C\left[z_{t}, u_{t} \mid W_{t-1}\right]=a$, where $a$ is perhaps a small number compared to $C\left[\eta_{t}, u_{t} \mid W_{t-1}\right]$, but is not zero. (Recall that $u_{t}$ is the residual from the outcome Equation (2), and that $\eta_{t}$ is the residual from the interest rate Equation (5)). We next consider the estimands of the OLS and IV estimators for $\theta$ when the instrument is not purely exogenous:

$$
\begin{gathered}
\hat{\theta}_{O L S} \stackrel{p}{=} \theta+\frac{\beta_{3} a+C\left[\eta_{t}, u_{t} \mid W_{t-1}\right]}{V\left[i_{t} \mid W_{t-1}\right]} \\
\hat{\theta}_{I V} \stackrel{p}{=} \theta+\frac{a}{C\left[z_{t}, i_{t} \mid W_{t-1}\right]} .
\end{gathered}
$$

Because the parameter $a$ is involved in both expressions, (12) and (13) imply a relationship between the bias of the OLS and IV estimators, notated $B_{O L S}$ and $B_{I V}$, respectively. Specifically, because $\beta_{3}=C\left[z_{t}, i_{t} \mid W_{t-1}\right] / V\left[z_{t} \mid W_{t-1}\right]$, we have

$$
\begin{aligned}
B_{O L S} & =\frac{C\left[z_{t}, i_{t} \mid W_{t-1}\right]}{V\left[z_{t} \mid W_{t-1}\right]} \frac{a}{V\left[i_{t} \mid W_{t-1}\right]}+\frac{C\left[\eta_{t}, u_{t} \mid W_{t-1}\right]}{V\left[i_{t} \mid W_{t-1}\right]} \\
& =\frac{C\left[z_{t}, i_{t} \mid W_{t-1}\right]}{V\left[i_{t} \mid W_{t-1}\right]} \frac{C\left[z_{t}, i_{t} \mid W_{t-1}\right]}{V\left[z_{t} \mid W_{t-1}\right]} B_{I V}+\frac{C\left[\eta_{t}, u_{t} \mid W_{t-1}\right]}{V\left[i_{t} \mid W_{t-1}\right]} \\
& \equiv \rho^{2} B_{I V}+b
\end{aligned}
$$

where $\rho$ denotes the correlation between $z_{t}$ and $i_{t}$ conditional on $W_{t-1}$. Under what conditions will least squares do worse than instrumental variables? Using equation (14), we see that

$$
B_{O L S}>B_{I V} \quad \Longleftrightarrow \quad B_{I V}<b /\left(1-\rho^{2}\right)
$$

since $1-\rho^{2}>0$ by the Schwartz inequality. The key term in the inequality in (14) is thus $b$, which should be approximately equal to the bias in a least squares estimate of the impact of monetary policy on the real economy using data on Germany, $B_{O L S}^{*}=$ 
$C\left[z_{t}, u_{t}^{*} \mid W_{t-1}^{*}\right] / V\left[z_{t} \mid W_{t-1}^{*}\right]$ (we presume that the relationship between German interest rates and output may be modeled by equations (2) and (5) without the instrument $z_{t}$ ). To further explore the bias, consider the (fictional) auxiliary population regression

$$
u_{t}=\eta u_{t}^{*}+\omega_{t}
$$

where $u_{t}^{*}$ are German output shocks in the German analogue to equation (2). Because this is a population projection, $\omega_{t}$ is the portion of home country output shocks that is orthogonal to German output shocks. We assume that in addition to this, $\omega_{t}$ is orthogonal to German interest rates, $z_{t}$ (we find this quite plausible, but it is a necessary assumption). This allows us to use Equation (16) to characterize the bias of the IV estimator as

$$
B_{I V}=\eta \frac{C\left[z_{t}, u_{t}^{*} \mid W_{t-1}\right]}{C\left[z_{t}, i_{t} \mid W_{t-1}\right]}=\frac{\eta}{\beta_{3}} \frac{C\left[z_{t}, u_{t}^{*} \mid W_{t-1}\right]}{V\left[z_{t} \mid W_{t-1}\right]} \equiv \frac{\eta}{\beta_{3}} \widetilde{B}_{O L S}^{*} \approx \frac{\eta}{\beta_{3}} B_{O L S}^{*} \approx \frac{\eta}{\beta_{3}} b,
$$

To gain intuition, formally treat the approximation in (17) as an equality. Then note that

$$
B_{I V}<\frac{b}{1-\rho^{2}} \quad \Longleftrightarrow \quad \frac{\eta}{\beta_{3}} b<\frac{1}{1-\rho^{2}} b \quad \Longleftrightarrow \quad \eta<\frac{\beta_{3}}{1-\rho^{2}},
$$

Empirically, $\beta_{3}$ is close to 0.8 and $\rho$ is close to 0.4 , leading the right hand side of (18) to be over $0.95 .{ }^{32}$ Because output shocks are unlikely to be correlated more than moderately, this leads to a fairly firm expectation that IV estimates will be less biased than OLS.

However, it is also possible to treat the approximation in (17) as an inequality. Specifically, it seems likely (although in principle not assured) that the bias in a German OLS estimate is reduced by inclusion of German control variables rather than foreign country controls. That would mean that $\widetilde{B}_{O L S}^{*}>B_{O L S}^{*}$. Moreover, since Germany is widely believed to have had a more effective central bank than most countries over this period, it is expected that $B_{O L S}^{*}>B_{O L S}$, i.e., that Germany's monetary policy was more forward-looking than that of other European countries. This leads to the the inequality chain $b<B_{O L S}^{*}<\widetilde{B}_{O L S}^{*}$ (recall that $b=B_{O L S}$ ). Combining these ideas, we see that

$$
B_{I V}<\frac{b}{1-\rho^{2}} \quad \Longleftrightarrow \quad \frac{\eta}{\beta_{3}} \widetilde{B}_{O L S}^{*}<\frac{1}{1-\rho^{2}} b \quad \Longleftrightarrow \quad \eta<\frac{b}{\widetilde{B}_{O L S}^{*}} \frac{\beta_{3}}{1-\rho^{2}}
$$

\footnotetext{
${ }^{32}$ Clearly both $\beta_{3}$ and $\rho$ will vary by country; we refer to pooled estimates of their magnitudes.
} 
which is a slightly attenuated version of the inequality in (18).

\section{References}

Angrist, Joshua and Alan Krueger, "Does Compulsory School Attendance Affect Earnings?," Quarterly Journal of Economics, November 1991, 106 (4).

Benigno, Gianluca, "Real Exchange Rate Persistence and Monetary Policy Rules," Journal of Monetary Economics, April 2004, 51 (3), 473-502.

Bernanke, Ben, "Alternative Explanations of the Money-Income Correlation," Carnegie Rochester Conference Series on Public Policy, Autumn 1986, (0), 49-99.

Bernanke, Ben S. and Alan S. Blinder, "The Federal Funds Rate and the Channels of Monetary Transmission," American Economic Review, September 1992, 82 (4), 902921.

and Ilian Mihov, "The Liquidity Effect and Long-Run Neutrality," Carnegie Rochester Conference Series on Public Policy, December 1998, 49, 149-194.

and Jean Boivin, "Monetary Policy in a Data-Rich Environment," Journal of Monetary Economics, 2004, 50 (3), 525-546.

and Poitr Eliasz, "Measuring the Effects of Monetary Policy: A FactorAugmented Vector Autoregressive (FAVAR) Approach," December 2003. Mimeo, Federal Reserve Board, Columbia University, and Princeton University.

Blanchard, Olivier J. and Mark Watson, Are All Business Cycles Alike?, Chicago, Il: University of Chicago Press, 1986.

Clarida, Jordi Gali Richard and Mark Gertler, "Monetary Policy Rules in Practice: Some International Evidence," European Economics Review, June 1998, 42 (6), 1033-1068. and __ "Monetary Policy Rules and Macroeconomic Stability: Evidence and Some Theory," The Quarterly Journal of Economics, February 2000, 115 (1), 147-180.

Clarida, Richard and Mark Gertler, How the Bundesbank Conducts Monetary Policy, Chicago, Il: University of Chicago Press, 1997.

Cushman, David O. and Tao Zha, "Identifying Monetary Policy in a Small Open Economy Under Flexible Exchange Rates," Journal of Monetary Economics, August 1997, 39 (3), 433-448.

Engel, Charles and Kenneth D. West, "Taylor Rules and the Deutschmark-Dollar Real Exchange Rate," 2004. Mimeo, University of Wisconsin.

Frankel, Jeffrey A. and Andrew K. Rose, "The Endogenity of the Optimum Currency Area Criteria," Economic Journal, July 1998, 108 (449), 1009-1025.

Friedman, Milton and Anna J. Schwartz, A Monetary History of the United States, 186701960, Princeton, NJ: Princeton University Press, 1963.

Gali, Jordi and Tommaso Monacelli, "Monetary Policy and Exchange Rate Volatitliy in a Small Open Economy," 2002. National Bureau of Economics Working Paper No. 8905. 
Giavazzi, Francesco and Alberto Giovannini, "Models of the EMS: Is Europe a Greater Deutschmark Area?," in Ralph C. Bryant and Richard Portes, eds., Global Macroeconomics, St. Martin's Press New York 1987.

and __ Limiting Exchange Rate Flexibility: The European Monetary System, Cambridge, Mass.: The MIT Press, 1989.

and Marco Pagano, "The Advantage of Tying One's Hands: EMS Discpline and Central Bank Credibility," European Economic Review, June 1988, 32 (5), 1027-1189.

Hamilton, James D., Time Series Analysis, Princeton, NJ: Princeton University Press, 1994.

Obstfeld, Maurice, Jay C. Shambaugh, and Alan M. Taylor, "Monetary Sovereignty, Exchange Rates, and Capital Controls: The Trilemma in the Interwar period," March 2004. NBER Working Paper No. 10393. and _ , "The Trilemma in History: Tradeoffs among Exchange Rates, Monetary Policies, and Capital Mobility," March 2004. NBER Working Paper No. 10396.

Romer, Christina D. and David H. Romer, "Does Monetary Policy Matter? A New Test in the Spirit of Friedman and Schwartz," in Oliver J. Blanchard and Stanley Fischer, eds., NBER Macroeconomics Annual 4, Cambridge, Mass.: The MIT Press, 1989, pp. 121170.

and __ "A New Measure of Monetary Shocks: Derivations and Implications," American Economic Review, September 2004, 94 (4), 1055-1084.

Shambaugh, Jay C., "The Effects of Fixed Exchange Rates on Monetary Policy," Quarterly Journal of Economics, 2004, 119 (1), 301-352.

Taylor, John B., "Discretion Versus Policy Rules in Practice," Carnegie Rochester Conference Series on Public Policy, December 93.

von Hagen, Juergen and Michele Fratianni, "German Dominance in the EMS: Evidence from Interest Rates," Journal of International Money and Finance, 1990, 9, 358-375. 
Table 1. The Effect of Interest Rates on the Real Economy:

Least Squares and Instrumental Variables Estimates

\begin{tabular}{|c|c|c|c|c|c|c|}
\hline \multirow[b]{2}{*}{ Country } & \multicolumn{3}{|c|}{ No Controls } & \multicolumn{3}{|c|}{ Four Lags of Inflation and Growth } \\
\hline & $\begin{array}{l}(1) \\
\text { OLS }\end{array}$ & $\begin{array}{l}\text { (2) } \\
\text { IV }\end{array}$ & $\begin{array}{c}3) \\
\text { OLS-IV } \\
\end{array}$ & $\begin{array}{c}(4) \\
\text { OLS } \\
\end{array}$ & $\begin{array}{l}\text { (5) } \\
\text { IV }\end{array}$ & $\begin{array}{c}(6) \\
\text { OLS-IV } \\
\end{array}$ \\
\hline Germany & $\begin{array}{l}-0.073 \\
(0.043) \\
{[0.041]}\end{array}$ & & & $\begin{array}{l}-0.064 \\
(0.048) \\
{[0.049]}\end{array}$ & & \\
\hline Great Britain & $\begin{array}{l}-0.058 \\
(0.031) \\
{[0.036]}\end{array}$ & $\begin{array}{l}-0.197 \\
(0.055) \\
{[0.069]}\end{array}$ & $\begin{array}{c}0.139 \\
(0.046) \\
{[0.060]}\end{array}$ & $\begin{array}{l}-0.059 \\
(0.025) \\
{[0.024]}\end{array}$ & $\begin{array}{l}-0.179 \\
(0.043) \\
{[0.052]}\end{array}$ & $\begin{array}{c}0.120 \\
(0.035) \\
{[0.047]}\end{array}$ \\
\hline France & $\begin{array}{l}-0.015 \\
(0.015) \\
{[0.016]}\end{array}$ & $\begin{array}{l}-0.074 \\
(0.035) \\
{[0.042]}\end{array}$ & $\begin{array}{c}0.059 \\
(0.032) \\
{[0.038]}\end{array}$ & $\begin{array}{l}-0.019 \\
(0.020) \\
{[0.026]}\end{array}$ & $\begin{array}{l}-0.072 \\
(0.035) \\
{[0.032]}\end{array}$ & $\begin{array}{c}0.053 \\
(0.029) \\
{[0.019]}\end{array}$ \\
\hline Italy & $\begin{array}{l}-0.024 \\
(0.018) \\
{[0.020]}\end{array}$ & $\begin{array}{l}-0.129 \\
(0.047) \\
{[0.070]}\end{array}$ & $\begin{array}{c}0.105 \\
(0.043) \\
{[0.067]}\end{array}$ & $\begin{array}{l}-0.034 \\
(0.023) \\
{[0.021]}\end{array}$ & $\begin{array}{l}-0.168 \\
(0.062) \\
{[0.059]}\end{array}$ & $\begin{array}{c}0.134 \\
(0.057) \\
{[0.056]}\end{array}$ \\
\hline Spain & $\begin{array}{l}-0.015 \\
(0.011) \\
{[0.015]}\end{array}$ & $\begin{array}{c}-0.180 \\
(0.078) \\
{[0.131]}\end{array}$ & $\begin{array}{c}0.165 \\
(0.077) \\
{[0.131]}\end{array}$ & $\begin{array}{c}0.002 \\
(0.005) \\
{[0.004]}\end{array}$ & $\begin{array}{l}-0.063 \\
(0.043) \\
{[0.053]}\end{array}$ & $\begin{array}{c}0.066 \\
(0.042) \\
{[0.053]}\end{array}$ \\
\hline Netherlands & $\begin{array}{l}-0.094 \\
(0.034) \\
{[0.029]}\end{array}$ & $\begin{array}{l}-0.145 \\
(0.050) \\
{[0.040]}\end{array}$ & $\begin{array}{c}0.051 \\
(0.036) \\
{[0.028]}\end{array}$ & $\begin{array}{c}-0.087 \\
(0.038) \\
{[0.038]}\end{array}$ & $\begin{array}{l}-0.140 \\
(0.060) \\
{[0.048]}\end{array}$ & $\begin{array}{c}0.052 \\
(0.046) \\
{[0.030]}\end{array}$ \\
\hline Switzerland & $\begin{array}{l}-0.016 \\
(0.041) \\
{[0.046]}\end{array}$ & $\begin{array}{l}-0.130 \\
(0.089) \\
{[0.088]}\end{array}$ & $\begin{array}{c}0.114 \\
(0.079) \\
{[0.074]}\end{array}$ & $\begin{array}{l}-0.015 \\
(0.040) \\
{[0.043]}\end{array}$ & $\begin{array}{l}-0.060 \\
(0.076) \\
{[0.058]}\end{array}$ & $\begin{array}{c}0.044 \\
(0.065) \\
{[0.039]}\end{array}$ \\
\hline Sweden & $\begin{array}{l}-0.055 \\
(0.034) \\
{[0.033]}\end{array}$ & $\begin{array}{l}-0.061 \\
(0.047) \\
{[0.042]}\end{array}$ & $\begin{array}{c}0.006 \\
(0.033) \\
{[0.026]}\end{array}$ & $\begin{array}{l}-0.085 \\
(0.060) \\
{[0.054]}\end{array}$ & $\begin{array}{l}-0.112 \\
(0.076) \\
{[0.071]}\end{array}$ & $\begin{array}{c}0.027 \\
(0.046) \\
{[0.047]}\end{array}$ \\
\hline Belgium & $\begin{array}{l}-0.031 \\
(0.063) \\
{[0.040]}\end{array}$ & $\begin{array}{l}-0.025 \\
(0.131) \\
{[0.079]}\end{array}$ & $\begin{array}{l}-0.006 \\
(0.114) \\
{[0.069]}\end{array}$ & $\begin{array}{l}-0.118 \\
(0.058) \\
{[0.059]}\end{array}$ & $\begin{array}{l}-0.174 \\
(0.136) \\
{[0.141]}\end{array}$ & $\begin{array}{c}0.056 \\
(0.123) \\
{[0.128]}\end{array}$ \\
\hline Austria & $\begin{array}{l}-0.069 \\
(0.085) \\
{[0.055]}\end{array}$ & $\begin{array}{l}-0.065 \\
(0.090) \\
{[0.058]}\end{array}$ & $\begin{array}{l}-0.004 \\
(0.028) \\
{[0.018]}\end{array}$ & $\begin{array}{l}-0.097 \\
(0.070) \\
{[0.074]}\end{array}$ & $\begin{array}{l}-0.072 \\
(0.090) \\
{[0.084]}\end{array}$ & $\begin{array}{l}-0.025 \\
(0.057) \\
{[0.039]}\end{array}$ \\
\hline Norway & $\begin{array}{l}-0.047 \\
(0.066) \\
{[0.050]}\end{array}$ & $\begin{array}{l}-0.175 \\
(0.196) \\
{[0.162]}\end{array}$ & $\begin{array}{c}0.128 \\
(0.184) \\
{[0.154]}\end{array}$ & $\begin{array}{c}-0.093 \\
(0.075) \\
{[0.074]}\end{array}$ & $\begin{array}{l}-0.435 \\
(0.286) \\
{[0.290]}\end{array}$ & $\begin{array}{c}0.342 \\
(0.276) \\
{[0.281]}\end{array}$ \\
\hline Portugal & $\begin{array}{l}-0.025 \\
(0.032) \\
{[0.024]}\end{array}$ & $\begin{array}{l}-0.068 \\
(0.062) \\
{[0.042]}\end{array}$ & $\begin{array}{c}0.044 \\
(0.054) \\
{[0.035]}\end{array}$ & $\begin{array}{l}-0.047 \\
(0.039) \\
{[0.039]}\end{array}$ & $\begin{array}{l}-0.104 \\
(0.083) \\
{[0.059]}\end{array}$ & $\begin{array}{c}0.057 \\
(0.073) \\
{[0.044]}\end{array}$ \\
\hline
\end{tabular}

Notes: The tables gives OLS and IV estimates of the effect of nominal interest rates on quarterly real economic growth. OLS estimates in columns (1) and (4) include four season indicators ("no controls") and four season indicators as well as four lags each of inflation and real economic growth, respectively. IV estimates in columns (2) and (5) use the same controls, but instrument home country interest rates with German interest rates. OLS-IV difference in columns (3) and (6) give the simple difference between the OLS and IV estimates. Standard errors in parentheses are Huber-Eicker-White standard errors and are robust to heteroskedasticity. Standard errors in square braces are fourth-order Newey-West standard errors and are robust to fourth order autocorrelation. 
Table 2. Summarizing Least Squares

\begin{tabular}{|c|c|c|c|c|c|}
\hline & & & Weig & Scheme & \\
\hline & & (1) & (2) & (3) & (4) \\
\hline & Controls & Equal & 2003 GDP (US\$) & $\begin{array}{c}\text { Non-Trade Fraction } \\
\text { of GDP }\end{array}$ & $\begin{array}{c}\text { Volatility, Nominal } \\
\text { Exchange Rate }\end{array}$ \\
\hline (A) & No Controls & $\begin{array}{l}-0.0325 \\
(0.0117) \\
{[0.0102]}\end{array}$ & $\begin{array}{l}-0.0300 \\
(0.0097) \\
{[0.0114]}\end{array}$ & $\begin{array}{l}-0.0318 \\
(0.0117) \\
{[0.0102]}\end{array}$ & $\begin{array}{l}-0.0296 \\
(0.0115) \\
{[0.0103]}\end{array}$ \\
\hline (B) & One Lag of Growth & $\begin{array}{l}-0.0411 \\
(0.0118) \\
{[0.0120]}\end{array}$ & $\begin{array}{l}-0.0319 \\
(0.0101) \\
{[0.0122]}\end{array}$ & $\begin{array}{l}-0.0404 \\
(0.0118) \\
{[0.0121]}\end{array}$ & $\begin{array}{l}-0.0384 \\
(0.0116) \\
{[0.0124]}\end{array}$ \\
\hline (C) & One Lag of Inflation & $\begin{array}{l}-0.0336 \\
(0.0140) \\
{[0.0124]}\end{array}$ & $\begin{array}{l}-0.0262 \\
(0.0107) \\
{[0.0123]}\end{array}$ & $\begin{array}{l}-0.0327 \\
(0.0139) \\
{[0.0124]}\end{array}$ & $\begin{array}{l}-0.0284 \\
(0.0130) \\
{[0.0118]}\end{array}$ \\
\hline (D) & $\begin{array}{l}\text { One Lag of Growth } \\
\text { and Inflation }\end{array}$ & $\begin{array}{l}-0.0379 \\
(0.0138) \\
{[0.0138]}\end{array}$ & $\begin{array}{l}-0.0272 \\
(0.0109) \\
{[0.0129]}\end{array}$ & $\begin{array}{l}-0.0370 \\
(0.0138) \\
{[0.0138]}\end{array}$ & $\begin{array}{l}-0.0329 \\
(0.0130) \\
{[0.0134]}\end{array}$ \\
\hline (E) & Four Lags of Growth & $\begin{array}{l}-0.0411 \\
(0.0123) \\
{[0.0127]}\end{array}$ & $\begin{array}{l}-0.0295 \\
(0.0105) \\
{[0.0121]}\end{array}$ & $\begin{array}{l}-0.0402 \\
(0.0123) \\
{[0.0127]}\end{array}$ & $\begin{array}{l}-0.0361 \\
(0.0121) \\
{[0.0127]}\end{array}$ \\
\hline (F) & Four Lags of Inflation & $\begin{array}{l}-0.0306 \\
(0.0154) \\
{[0.0132]}\end{array}$ & $\begin{array}{l}-0.0211 \\
(0.0113) \\
{[0.0125]}\end{array}$ & $\begin{array}{l}-0.0299 \\
(0.0154) \\
{[0.0132]}\end{array}$ & $\begin{array}{l}-0.0252 \\
(0.0140) \\
{[0.0125]}\end{array}$ \\
\hline (G) & $\begin{array}{l}\text { Four Lags of Growth } \\
\text { and Inflation }\end{array}$ & $\begin{array}{l}-0.0353 \\
(0.0156) \\
{[0.0158]}\end{array}$ & $\begin{array}{l}-0.0203 \\
(0.0120) \\
{[0.0130]}\end{array}$ & $\begin{array}{l}-0.0344 \\
(0.0156) \\
{[0.0158]}\end{array}$ & $\begin{array}{l}-0.0283 \\
(0.0144) \\
{[0.0148]}\end{array}$ \\
\hline (H) & $\begin{array}{l}\text { One Lag of Growth } \\
\text { and Inflation, Different } \\
\text { for each Country }\end{array}$ & $\begin{array}{l}-0.0464 \\
(0.0143) \\
{[0.0154]}\end{array}$ & $\begin{array}{l}-0.0369 \\
(0.0107) \\
{[0.0123]}\end{array}$ & $\begin{array}{l}-0.0456 \\
(0.0143) \\
{[0.0154]}\end{array}$ & $\begin{array}{l}-0.0412 \\
(0.0131) \\
{[0.0142]}\end{array}$ \\
\hline (I) & $\begin{array}{l}\text { Four Lags of Growth } \\
\text { and Inflation, Different } \\
\text { for each Country }\end{array}$ & $\begin{array}{l}-0.0497 \\
(0.0148) \\
{[0.0160]}\end{array}$ & $\begin{array}{l}-0.0374 \\
(0.0109) \\
{[0.0124]}\end{array}$ & $\begin{array}{l}-0.0488 \\
(0.0148) \\
{[0.0160]}\end{array}$ & $\begin{array}{l}-0.0447 \\
(0.0134) \\
{[0.0147]}\end{array}$ \\
\hline & Average Coefficient & -0.0413 & -0.0315 & -0.0405 & -0.0365 \\
\hline & Median Coefficient & -0.0411 & -0.0319 & -0.0404 & -0.0384 \\
\hline & Standard Deviation & 0.0067 & 0.0063 & 0.0067 & 0.0068 \\
\hline
\end{tabular}

Note: Table gives pooled OLS estimates of the impact of nominal interest rates on quarterly real GDP growth for all countries except Germany. Estimation includes the control variables specified under "Controls" and uses country-specific weights described in the column heading. Each estimate includes season indicators fully interacted country indicators. In Columns $(\mathrm{H})$ and $(\mathrm{I})$, lags are chosen separately for each countries using significance levels. Column (1) gives estimates that are equally weighted.

Column (2) gives estimates based on weights that are proportional to a country's 2003 level of GDP in US dollars. Column (3) gives estimates that are weighted by one minus the fraction of a country's GDP that stems from trade with Germany. Column (4) gives estimates that are weighted by the volatility of the nominal exchange rate. The last three rows report the mean, median, and standard deviation of the coefficient estimates in columns (A) to (I) plus additional specifications with different sets of different lags for each countries. Huber-Eicker-White standard errors in parentheses, and fourth-order Newey-West standard errors in square brackets. 
Table 3. Summarizing Instrumental Variables

\begin{tabular}{|c|c|c|c|c|c|}
\hline & & & Weig & Scheme & \\
\hline & & (1) & (2) & (3) & (4) \\
\hline & Controls & Equal & 2003 GDP (US\$) & $\begin{array}{c}\text { Non-Trade Fraction } \\
\text { of GDP } \\
\end{array}$ & $\begin{array}{c}\text { Volatility, Nominal } \\
\text { Exchange Rate }\end{array}$ \\
\hline (A) & No Controls & $\begin{array}{l}-0.1073 \\
(0.0242) \\
{[0.0215]}\end{array}$ & $\begin{array}{l}-0.1209 \\
(0.0214) \\
{[0.0274]}\end{array}$ & $\begin{array}{l}-0.1083 \\
(0.0245) \\
{[0.0220]}\end{array}$ & $\begin{array}{l}-0.1150 \\
(0.0260) \\
{[0.0241]}\end{array}$ \\
\hline (B) & One Lag of Growth & $\begin{array}{l}-0.1297 \\
(0.0250) \\
{[0.0239]}\end{array}$ & $\begin{array}{l}-0.1321 \\
(0.0232) \\
{[0.0301]}\end{array}$ & $\begin{array}{l}-0.1315 \\
(0.0254) \\
{[0.0246]}\end{array}$ & $\begin{array}{l}-0.1419 \\
(0.0270) \\
{[0.0276]}\end{array}$ \\
\hline (C) & One Lag of Inflation & $\begin{array}{l}-0.1166 \\
(0.0266) \\
{[0.0230]}\end{array}$ & $\begin{array}{l}-0.1286 \\
(0.0239) \\
{[0.0298]}\end{array}$ & $\begin{array}{l}-0.1175 \\
(0.0269) \\
{[0.0235]}\end{array}$ & $\begin{array}{l}-0.1228 \\
(0.0284) \\
{[0.0259]}\end{array}$ \\
\hline (D) & $\begin{array}{l}\text { One Lag of Growth } \\
\text { and Inflation }\end{array}$ & $\begin{array}{l}-0.1349 \\
(0.0271) \\
{[0.0254]}\end{array}$ & $\begin{array}{l}-0.1381 \\
(0.0252) \\
{[0.0319]}\end{array}$ & $\begin{array}{l}-0.1366 \\
(0.0275) \\
{[0.0260]}\end{array}$ & $\begin{array}{l}-0.1460 \\
(0.0291) \\
{[0.0293]}\end{array}$ \\
\hline (E) & Four Lags of Growth & $\begin{array}{l}-0.1362 \\
(0.0253) \\
{[0.0250]}\end{array}$ & $\begin{array}{l}-0.1262 \\
(0.0232) \\
{[0.0291]}\end{array}$ & $\begin{array}{l}-0.1379 \\
(0.0258) \\
{[0.0257]}\end{array}$ & $\begin{array}{l}-0.1439 \\
(0.0278) \\
{[0.0284]}\end{array}$ \\
\hline (F) & Four Lags of Inflation & $\begin{array}{l}-0.1247 \\
(0.0305) \\
{[0.0261]}\end{array}$ & $\begin{array}{l}-0.1331 \\
(0.0258) \\
{[0.0318]}\end{array}$ & $\begin{array}{l}-0.1258 \\
(0.0309) \\
{[0.0267]}\end{array}$ & $\begin{array}{l}-0.1315 \\
(0.0324) \\
{[0.0296]}\end{array}$ \\
\hline (G) & $\begin{array}{l}\text { Four Lags of Growth } \\
\text { and Inflation }\end{array}$ & $\begin{array}{l}-0.1524 \\
(0.0313) \\
{[0.0301]}\end{array}$ & $\begin{array}{l}-0.1353 \\
(0.0266) \\
{[0.0323]}\end{array}$ & $\begin{array}{l}-0.1543 \\
(0.0318) \\
{[0.0309]}\end{array}$ & $\begin{array}{l}-0.1588 \\
(0.0339) \\
{[0.0341]}\end{array}$ \\
\hline (H) & $\begin{array}{l}\text { One Lag of Growth } \\
\text { and Inflation, Different } \\
\text { for each Country }\end{array}$ & $\begin{array}{l}-0.1322 \\
(0.0299) \\
{[0.0281]}\end{array}$ & $\begin{array}{l}-0.1228 \\
(0.0222) \\
{[0.0231]}\end{array}$ & $\begin{array}{l}-0.1335 \\
(0.0303) \\
{[0.0286]}\end{array}$ & $\begin{array}{l}-0.1381 \\
(0.0309) \\
{[0.0299]}\end{array}$ \\
\hline (I) & $\begin{array}{l}\text { Four Lags of Growth } \\
\text { and Inflation, Different } \\
\text { for each Country }\end{array}$ & $\begin{array}{l}-0.1338 \\
(0.0301) \\
{[0.0281]}\end{array}$ & $\begin{array}{l}-0.1231 \\
(0.0223) \\
{[0.0232]}\end{array}$ & $\begin{array}{l}-0.1352 \\
(0.0305) \\
{[0.0287]}\end{array}$ & $\begin{array}{l}-0.1405 \\
(0.0311) \\
{[0.0298]}\end{array}$ \\
\hline & Average Coefficient & -0.1306 & -0.1282 & -0.1317 & -0.1376 \\
\hline & Median Coefficient & -0.1322 & -0.1282 & -0.1335 & -0.1405 \\
\hline & Standard Deviation & 0.0106 & 0.0055 & 0.0109 & 0.0109 \\
\hline
\end{tabular}

Note: Table gives pooled IV estimates of the impact of nominal interest rates on quarterly real GDP growth for all countries using German 'nominal interest rates as an instrument for home country interest rates. See Table 2 for additional details on table interpretation. 
Table 4. Comovements in European Nominal Interest Rates

(1)

(2)

(3)

(4)

(5)

\begin{tabular}{|c|c|c|c|c|c|}
\hline Country & No Controls & $\begin{array}{l}\text { One Lag of } \\
\text { Growth }\end{array}$ & $\begin{array}{l}\text { One Lag of } \\
\text { Growth and } \\
\text { Inflation }\end{array}$ & $\begin{array}{c}\text { Four Lags of } \\
\text { Growth } \\
\end{array}$ & $\begin{array}{l}\text { Four Lags of } \\
\text { Growth and } \\
\text { Inflation } \\
\end{array}$ \\
\hline Great Britain & $\begin{array}{c}0.750 \\
(0.126) \\
{[0.210]}\end{array}$ & $\begin{array}{c}0.764 \\
(0.140) \\
{[0.206]}\end{array}$ & $\begin{array}{c}0.766 \\
(0.143) \\
{[0.208]}\end{array}$ & $\begin{array}{c}0.957 \\
(0.168) \\
{[0.248]}\end{array}$ & $\begin{array}{c}1.147 \\
(0.153) \\
{[0.218]}\end{array}$ \\
\hline France & $\begin{array}{c}1.264 \\
(0.247) \\
{[0.315]}\end{array}$ & $\begin{array}{c}1.304 \\
(0.259) \\
{[0.323]}\end{array}$ & $\begin{array}{c}1.121 \\
(0.236) \\
{[0.219]}\end{array}$ & $\begin{array}{c}1.302 \\
(0.248) \\
{[0.318]}\end{array}$ & $\begin{array}{c}1.113 \\
(0.215) \\
{[0.204]}\end{array}$ \\
\hline Italy & $\begin{array}{c}0.950 \\
(0.199) \\
{[0.316]}\end{array}$ & $\begin{array}{c}0.964 \\
(0.211) \\
{[0.324]}\end{array}$ & $\begin{array}{c}0.611 \\
(0.196) \\
{[0.231]}\end{array}$ & $\begin{array}{c}0.957 \\
(0.215) \\
{[0.339]}\end{array}$ & $\begin{array}{c}0.583 \\
(0.165) \\
{[0.187]}\end{array}$ \\
\hline Spain & $\begin{array}{c}0.488 \\
(0.194) \\
{[0.338]}\end{array}$ & $\begin{array}{c}0.421 \\
(0.179) \\
{[0.305]}\end{array}$ & $\begin{array}{c}0.411 \\
(0.181) \\
{[0.276]}\end{array}$ & $\begin{array}{c}0.418 \\
(0.187) \\
{[0.318]}\end{array}$ & $\begin{array}{c}0.441 \\
(0.183) \\
{[0.263]}\end{array}$ \\
\hline Netherlands & $\begin{array}{c}0.870 \\
(0.085) \\
{[0.110]}\end{array}$ & $\begin{array}{c}0.866 \\
(0.091) \\
{[0.113]}\end{array}$ & $\begin{array}{c}0.811 \\
(0.098) \\
{[0.124]}\end{array}$ & $\begin{array}{c}0.877 \\
(0.093) \\
{[0.123]}\end{array}$ & $\begin{array}{c}0.793 \\
(0.105) \\
{[0.146]}\end{array}$ \\
\hline Switzerland & $\begin{array}{c}0.559 \\
(0.122) \\
{[0.243]}\end{array}$ & $\begin{array}{c}0.559 \\
(0.123) \\
{[0.244]}\end{array}$ & $\begin{array}{c}0.635 \\
(0.139) \\
{[0.258]}\end{array}$ & $\begin{array}{c}0.552 \\
(0.128) \\
{[0.253]}\end{array}$ & $\begin{array}{c}0.702 \\
(0.159) \\
{[0.279]}\end{array}$ \\
\hline Sweden & $\begin{array}{c}1.033 \\
(0.075) \\
{[0.104]}\end{array}$ & $\begin{array}{c}1.012 \\
(0.076) \\
{[0.106]}\end{array}$ & $\begin{array}{c}0.820 \\
(0.074) \\
{[0.100]}\end{array}$ & $\begin{array}{c}0.974 \\
(0.082) \\
{[0.114]}\end{array}$ & $\begin{array}{c}0.707 \\
(0.064) \\
{[0.088]}\end{array}$ \\
\hline Belgium & $\begin{array}{c}1.105 \\
(0.200) \\
{[0.254]}\end{array}$ & $\begin{array}{c}1.080 \\
(0.191) \\
{[0.253]}\end{array}$ & $\begin{array}{c}1.080 \\
(0.194) \\
{[0.252]}\end{array}$ & $\begin{array}{c}1.010 \\
(0.201) \\
{[0.309]}\end{array}$ & $\begin{array}{c}0.910 \\
(0.237) \\
{[0.312]}\end{array}$ \\
\hline Austria & $\begin{array}{c}0.838 \\
(0.060) \\
{[0.089]}\end{array}$ & $\begin{array}{c}0.839 \\
(0.061) \\
{[0.091]}\end{array}$ & $\begin{array}{c}0.820 \\
(0.060) \\
{[0.088]}\end{array}$ & $\begin{array}{c}0.833 \\
(0.063) \\
{[0.093]}\end{array}$ & $\begin{array}{c}0.787 \\
(0.063) \\
{[0.093]}\end{array}$ \\
\hline Norway & $\begin{array}{c}0.596 \\
(0.177) \\
{[0.270]}\end{array}$ & $\begin{array}{c}0.573 \\
(0.169) \\
{[0.267]}\end{array}$ & $\begin{array}{c}0.560 \\
(0.174) \\
{[0.268]}\end{array}$ & $\begin{array}{c}0.488 \\
(0.185) \\
{[0.290]}\end{array}$ & $\begin{array}{c}0.495 \\
(0.209) \\
{[0.304]}\end{array}$ \\
\hline Portugal & $\begin{array}{c}1.143 \\
(0.191) \\
{[0.345]}\end{array}$ & $\begin{array}{c}1.125 \\
(0.196) \\
{[0.348]}\end{array}$ & $\begin{array}{c}1.008 \\
(0.191) \\
{[0.263]}\end{array}$ & $\begin{array}{c}1.098 \\
(0.198) \\
{[0.354]}\end{array}$ & $\begin{array}{c}0.912 \\
(0.146) \\
{[0.211]}\end{array}$ \\
\hline
\end{tabular}

Notes: The tables gives OLS estimates of the effect of nominal German interest rates on nominal interest rates for countries specified, controlling for effects specified in column headings in addition to four season indicators. In parentheses are Huber-Eicker-White standard errors, which are robust to heteroskedasticity. In brackets are fourth-order Newey-West standard errors, which are robust to fourth order autocorrelation. 
Table 5. Summarizing the Strength of the First Stage Relationship

\begin{tabular}{|c|c|c|c|c|c|}
\hline & & & Weig & Scheme & \\
\hline & & (1) & (2) & (3) & (4) \\
\hline & Controls & Equal & 2003 GDP (US\$) & $\begin{array}{c}\text { Non-Trade Fraction } \\
\text { of GDP }\end{array}$ & $\begin{array}{c}\text { Volatility, Nominal } \\
\text { Exchange Rate }\end{array}$ \\
\hline (A) & No Controls & $\begin{array}{c}0.8539 \\
(0.0524) \\
{[0.0852]}\end{array}$ & $\begin{array}{c}0.8987 \\
(0.0820) \\
{[0.1252]}\end{array}$ & $\begin{array}{c}0.8529 \\
(0.0544) \\
{[0.0882]}\end{array}$ & $\begin{array}{c}0.8346 \\
(0.0607) \\
{[0.1009]}\end{array}$ \\
\hline (B) & One Lag of Growth & $\begin{array}{c}0.8449 \\
(0.0525) \\
{[0.0854]}\end{array}$ & $\begin{array}{c}0.8981 \\
(0.0844) \\
{[0.1272]}\end{array}$ & $\begin{array}{c}0.8436 \\
(0.0544) \\
{[0.0884]}\end{array}$ & $\begin{array}{c}0.8225 \\
(0.0608) \\
{[0.1010]}\end{array}$ \\
\hline (C) & One Lag of Inflation & $\begin{array}{c}0.7895 \\
(0.0527) \\
{[0.0792]}\end{array}$ & $\begin{array}{c}0.8220 \\
(0.0792) \\
{[0.1120]}\end{array}$ & $\begin{array}{c}0.7883 \\
(0.0545) \\
{[0.0818]}\end{array}$ & $\begin{array}{c}0.7702 \\
(0.0609) \\
{[0.0928]}\end{array}$ \\
\hline (D) & $\begin{array}{l}\text { One Lag of Growth } \\
\text { and Inflation }\end{array}$ & $\begin{array}{c}0.7894 \\
(0.0527) \\
{[0.0794]}\end{array}$ & $\begin{array}{c}0.8340 \\
(0.0813) \\
{[0.1135]}\end{array}$ & $\begin{array}{c}0.7881 \\
(0.0546) \\
{[0.0820]}\end{array}$ & $\begin{array}{c}0.7695 \\
(0.0609) \\
{[0.0929]}\end{array}$ \\
\hline (E) & Four Lags of Growth & $\begin{array}{c}0.8335 \\
(0.0526) \\
{[0.0863]}\end{array}$ & $\begin{array}{c}0.9100 \\
(0.0831) \\
{[0.1270]}\end{array}$ & $\begin{array}{c}0.8316 \\
(0.0546) \\
{[0.0894]}\end{array}$ & $\begin{array}{c}0.8088 \\
(0.0615) \\
{[0.1027]}\end{array}$ \\
\hline (F) & Four Lags of Inflation & $\begin{array}{c}0.7143 \\
(0.0538) \\
{[0.0803]}\end{array}$ & $\begin{array}{c}0.7702 \\
(0.0788) \\
{[0.1124]}\end{array}$ & $\begin{array}{c}0.7129 \\
(0.0557) \\
{[0.0826]}\end{array}$ & $\begin{array}{c}0.6933 \\
(0.0623) \\
{[0.0941]}\end{array}$ \\
\hline (G) & $\begin{array}{l}\text { Four Lags of Growth } \\
\text { and Inflation }\end{array}$ & $\begin{array}{c}0.7100 \\
(0.0538) \\
{[0.0817]}\end{array}$ & $\begin{array}{c}0.8024 \\
(0.0805) \\
{[0.1162]}\end{array}$ & $\begin{array}{c}0.7084 \\
(0.0557) \\
{[0.0842]}\end{array}$ & $\begin{array}{c}0.6900 \\
(0.0626) \\
{[0.0964]}\end{array}$ \\
\hline (H) & $\begin{array}{l}\text { One Lag of Growth } \\
\text { and Inflation, Different } \\
\text { for each Country }\end{array}$ & $\begin{array}{c}0.7684 \\
(0.0543) \\
{[0.0741]}\end{array}$ & $\begin{array}{c}0.8288 \\
(0.0802) \\
{[0.0961]}\end{array}$ & $\begin{array}{c}0.7680 \\
(0.0564) \\
{[0.0767]}\end{array}$ & $\begin{array}{c}0.7624 \\
(0.0647) \\
{[0.0895]}\end{array}$ \\
\hline (I) & $\begin{array}{l}\text { Four Lags of Growth } \\
\text { and Inflation, Different } \\
\text { for each Country }\end{array}$ & $\begin{array}{c}0.7602 \\
(0.0528) \\
{[0.0720]}\end{array}$ & $\begin{array}{c}0.8271 \\
(0.0803) \\
{[0.0963]}\end{array}$ & $\begin{array}{c}0.7596 \\
(0.0548) \\
{[0.0745]}\end{array}$ & $\begin{array}{c}0.7508 \\
(0.0621) \\
{[0.0858]}\end{array}$ \\
\hline & Average Coefficient & 0.7777 & 0.8297 & 0.7766 & 0.7621 \\
\hline & Median Coefficient & 0.7804 & 0.8288 & 0.7805 & 0.7695 \\
\hline & Standard Deviation & 0.0461 & 0.0487 & 0.0462 & 0.0463 \\
\hline
\end{tabular}

Note: Table gives pooled OLS estimates of the impact of German nominal interest rates on nominal interest rates for non-German countries. See Table 2 for additional details on table interpretation. 
Table 6. Baseline OLS and IV Estimates for the EMS Period

\begin{tabular}{|c|c|c|c|c|c|c|}
\hline \multirow[b]{2}{*}{ Country } & \multicolumn{3}{|c|}{ No Controls } & \multicolumn{3}{|c|}{ Four Lags of Inflation and Growth } \\
\hline & $\begin{array}{c}(1) \\
\text { OLS }\end{array}$ & $\begin{array}{l}\text { (2) } \\
\text { IV }\end{array}$ & $\begin{array}{c}\text { (3) } \\
\text { OLS-IV }\end{array}$ & $\begin{array}{c}\text { (4) } \\
\text { OLS }\end{array}$ & $\begin{array}{l}\text { (5) } \\
\text { IV }\end{array}$ & $\begin{array}{c}(6) \\
\text { OLS-IV }\end{array}$ \\
\hline Germany & $\begin{array}{l}-0.036 \\
(0.046) \\
{[0.044]}\end{array}$ & & & $\begin{array}{l}-0.003 \\
(0.071) \\
{[0.058]}\end{array}$ & $\begin{array}{l}-0.003 \\
(0.071) \\
{[0.058]}\end{array}$ & \\
\hline Great Britain & $\begin{array}{l}-0.108 \\
(0.026) \\
{[0.035]}\end{array}$ & $\begin{array}{c}-0.218 \\
(0.054) \\
{[0.070]}\end{array}$ & $\begin{array}{c}0.110 \\
(0.047) \\
{[0.061]}\end{array}$ & $\begin{array}{l}-0.028 \\
(0.042) \\
{[0.039]}\end{array}$ & $\begin{array}{l}-0.252 \\
(0.233) \\
{[0.306]}\end{array}$ & $\begin{array}{c}0.224 \\
(0.230) \\
{[0.304]}\end{array}$ \\
\hline France & $\begin{array}{l}-0.014 \\
(0.014) \\
{[0.017]}\end{array}$ & $\begin{array}{l}-0.050 \\
(0.027) \\
{[0.032]}\end{array}$ & $\begin{array}{c}0.036 \\
(0.023) \\
{[0.027]}\end{array}$ & $\begin{array}{l}-0.004 \\
(0.022) \\
{[0.029]}\end{array}$ & $\begin{array}{l}-0.054 \\
(0.036) \\
{[0.034]}\end{array}$ & $\begin{array}{c}0.050 \\
(0.029) \\
{[0.018]}\end{array}$ \\
\hline Italy & $\begin{array}{l}-0.026 \\
(0.015) \\
{[0.013]}\end{array}$ & $\begin{array}{l}-0.064 \\
(0.025) \\
{[0.029]}\end{array}$ & $\begin{array}{c}0.038 \\
(0.020) \\
{[0.025]}\end{array}$ & $\begin{array}{l}-0.047 \\
(0.027) \\
{[0.025]}\end{array}$ & $\begin{array}{l}-0.148 \\
(0.061) \\
{[0.060]}\end{array}$ & $\begin{array}{c}0.102 \\
(0.055) \\
{[0.054]}\end{array}$ \\
\hline Spain & $\begin{array}{l}-0.033 \\
(0.009) \\
{[0.015]}\end{array}$ & $\begin{array}{l}-0.139 \\
(0.039) \\
{[0.070]}\end{array}$ & $\begin{array}{c}0.106 \\
(0.038) \\
{[0.068]}\end{array}$ & $\begin{array}{c}0.004 \\
(0.008) \\
{[0.007]}\end{array}$ & $\begin{array}{c}-0.052 \\
(0.039) \\
{[0.041]}\end{array}$ & $\begin{array}{c}0.056 \\
(0.039) \\
{[0.040]}\end{array}$ \\
\hline Netherlands & $\begin{array}{l}-0.102 \\
(0.034) \\
{[0.027]}\end{array}$ & $\begin{array}{l}-0.137 \\
(0.048) \\
{[0.040]}\end{array}$ & $\begin{array}{c}0.035 \\
(0.033) \\
{[0.029]}\end{array}$ & $\begin{array}{l}-0.093 \\
(0.039) \\
{[0.039]}\end{array}$ & $\begin{array}{c}-0.122 \\
(0.060) \\
{[0.049]}\end{array}$ & $\begin{array}{c}0.029 \\
(0.045) \\
{[0.030]}\end{array}$ \\
\hline Switzerland & $\begin{array}{l}-0.040 \\
(0.035) \\
{[0.048]}\end{array}$ & $\begin{array}{l}-0.129 \\
(0.061) \\
{[0.077]}\end{array}$ & $\begin{array}{c}0.089 \\
(0.050) \\
{[0.061]}\end{array}$ & $\begin{array}{c}-0.028 \\
(0.033) \\
{[0.031]}\end{array}$ & $\begin{array}{l}-0.091 \\
(0.060) \\
{[0.055]}\end{array}$ & $\begin{array}{c}0.062 \\
(0.050) \\
{[0.046]}\end{array}$ \\
\hline Sweden & $\begin{array}{l}-0.055 \\
(0.034) \\
{[0.033]}\end{array}$ & $\begin{array}{l}-0.061 \\
(0.047) \\
{[0.042]}\end{array}$ & $\begin{array}{c}0.006 \\
(0.033) \\
{[0.026]}\end{array}$ & $\begin{array}{l}-0.085 \\
(0.060) \\
{[0.054]}\end{array}$ & $\begin{array}{l}-0.112 \\
(0.076) \\
{[0.071]}\end{array}$ & $\begin{array}{c}0.027 \\
(0.046) \\
{[0.047]}\end{array}$ \\
\hline Belgium & $\begin{array}{l}-0.031 \\
(0.063) \\
{[0.040]}\end{array}$ & $\begin{array}{l}-0.025 \\
(0.131) \\
{[0.079]}\end{array}$ & $\begin{array}{l}-0.006 \\
(0.114) \\
{[0.069]}\end{array}$ & $\begin{array}{c}-0.118 \\
(0.058) \\
{[0.059]}\end{array}$ & $\begin{array}{l}-0.174 \\
(0.136) \\
{[0.141]}\end{array}$ & $\begin{array}{c}0.056 \\
(0.123) \\
{[0.128]}\end{array}$ \\
\hline Austria & $\begin{array}{l}-0.024 \\
(0.076) \\
{[0.048]}\end{array}$ & $\begin{array}{l}-0.033 \\
(0.083) \\
{[0.054]}\end{array}$ & $\begin{array}{c}0.010 \\
(0.033) \\
{[0.024]}\end{array}$ & $\begin{array}{l}-0.030 \\
(0.075) \\
{[0.083]}\end{array}$ & $\begin{array}{l}-0.079 \\
(0.120) \\
{[0.115]}\end{array}$ & $\begin{array}{c}0.048 \\
(0.094) \\
{[0.080]}\end{array}$ \\
\hline Norway & $\begin{array}{l}-0.098 \\
(0.058) \\
{[0.035]}\end{array}$ & $\begin{array}{c}-0.074 \\
(0.140) \\
{[0.100]}\end{array}$ & $\begin{array}{l}-0.024 \\
(0.127) \\
{[0.093]}\end{array}$ & $\begin{array}{c}-0.148 \\
(0.048) \\
{[0.045]}\end{array}$ & $\begin{array}{l}-0.138 \\
(0.195) \\
{[0.166]}\end{array}$ & $\begin{array}{l}-0.010 \\
(0.188) \\
{[0.160]}\end{array}$ \\
\hline Portugal & $\begin{array}{l}-0.028 \\
(0.031) \\
{[0.023]}\end{array}$ & $\begin{array}{l}-0.059 \\
(0.053) \\
{[0.035]}\end{array}$ & $\begin{array}{c}0.032 \\
(0.043) \\
{[0.026]}\end{array}$ & $\begin{array}{l}-0.053 \\
(0.040) \\
{[0.040]}\end{array}$ & $\begin{array}{l}-0.089 \\
(0.074) \\
{[0.051]}\end{array}$ & $\begin{array}{c}0.035 \\
(0.063) \\
{[0.032]}\end{array}$ \\
\hline
\end{tabular}

Notes: Table gives OLS and IV estimates, where estimation begins in 1979. See Table 1 for details. Results for pooled models are reported in the text. 


\section{Figure 1. IV and OLS-IV and Country Characteristics}

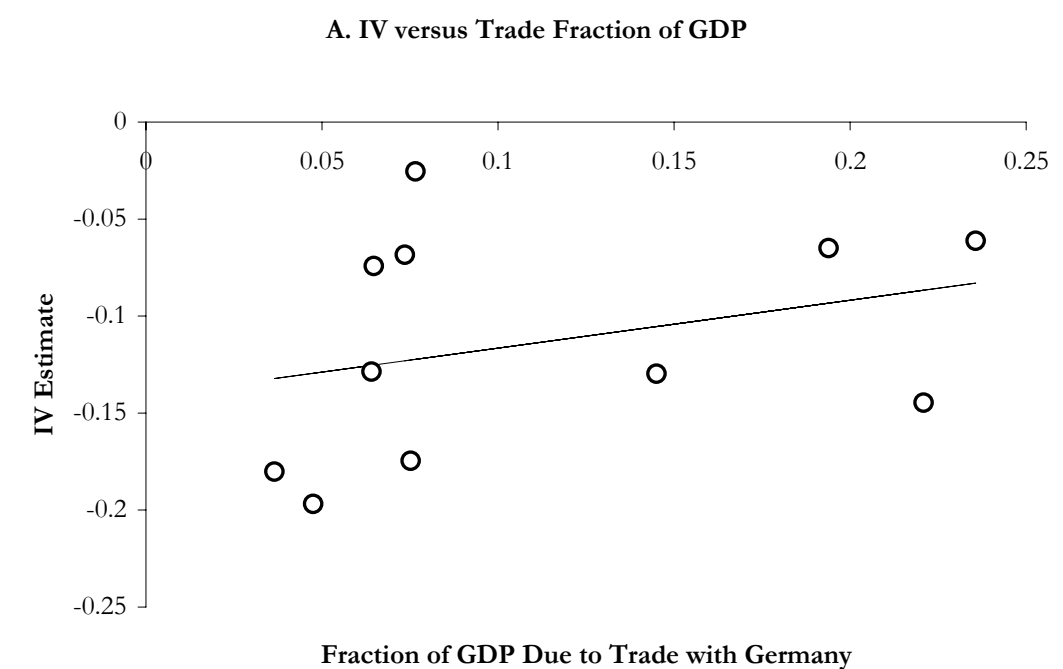

C. OLS-IV Difference versus Trade Fraction of GDP

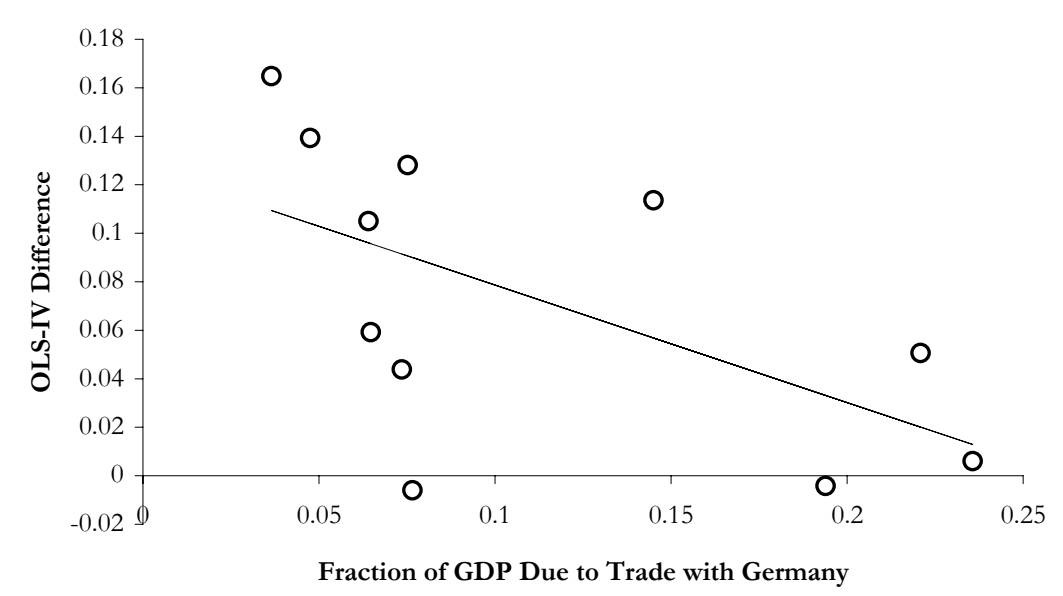

B. IV versus Exchange Rate Volatility

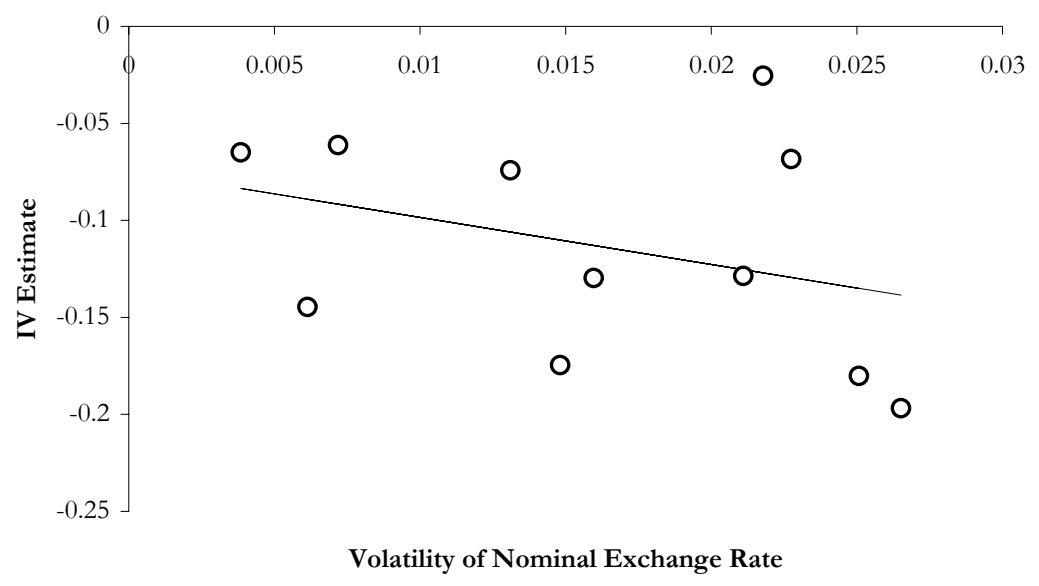

D. OLS-IV Difference versus Exchange Rate Volatility

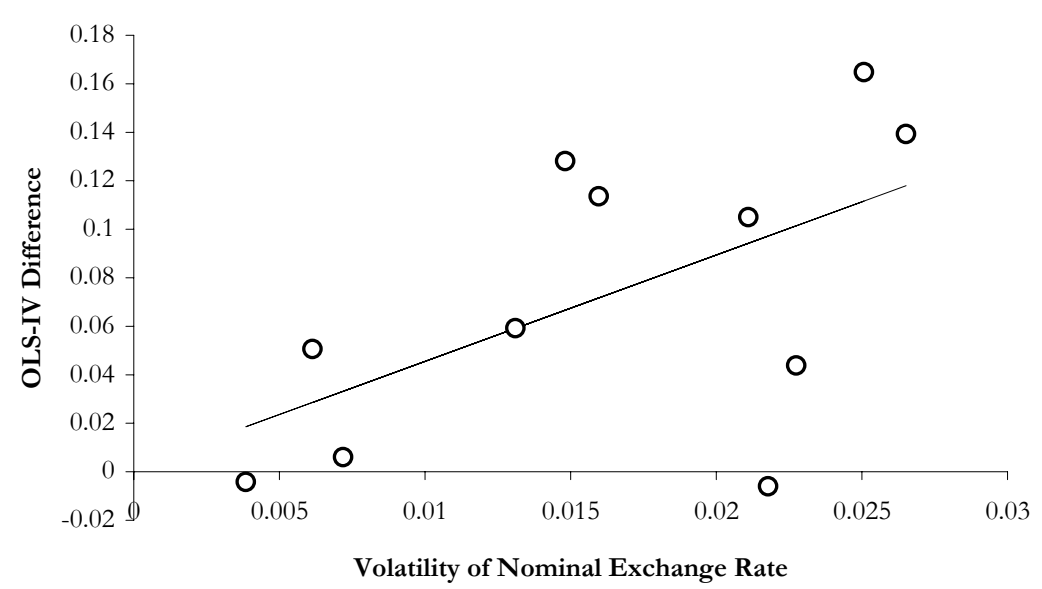


Table A.1. Country Summary Statistics

\begin{tabular}{|c|c|c|c|c|c|c|}
\hline & & & & & & \\
\hline Country & GDP & Trade/GDP & sd(NER) & GDP Growth & Interest Rate & Inflation \\
\hline Austria & 251.46 & 0.194 & 0.004 & 0.005 & 0.065 & 0.038 \\
\hline & - & - & - & $(0.081)$ & $(0.023)$ & $(0.018)$ \\
\hline Belgium & 302.22 & 0.236 & 0.007 & 0.005 & 0.070 & 0.029 \\
\hline & - & - & - & $(0.081)$ & $(0.023)$ & $(0.018)$ \\
\hline France & 1747.97 & 0.065 & 0.013 & 0.005 & 0.096 & 0.059 \\
\hline & - & - & - & $(0.007)$ & $(0.043)$ & $(0.040)$ \\
\hline Germany & 2400.66 & - & - & 0.005 & 0.060 & 0.032 \\
\hline & - & - & - & $(0.010)$ & $(0.023)$ & $(0.015)$ \\
\hline Great Britain & 1794.86 & 0.047 & 0.027 & 0.005 & 0.090 & 0.076 \\
\hline & - & - & - & $(0.010)$ & $(0.037)$ & $(0.055)$ \\
\hline Italy & 1465.90 & 0.064 & 0.021 & 0.005 & 0.124 & 0.096 \\
\hline & - & - & - & $(0.008)$ & $(0.042)$ & $(0.054)$ \\
\hline Netherlands & 511.56 & 0.221 & 0.006 & 0.006 & 0.066 & 0.021 \\
\hline & - & - & - & $(0.009)$ & $(0.025)$ & $(0.016)$ \\
\hline Norway & 221.58 & 0.075 & 0.015 & 0.010 & 0.101 & 0.050 \\
\hline & - & - & - & $(0.041)$ & $(0.040)$ & $(0.038)$ \\
\hline Portugal & 149.45 & 0.074 & 0.023 & 0.007 & 0.147 & 0.130 \\
\hline & - & - & - & $(0.019)$ & $(0.053)$ & $(0.078)$ \\
\hline Spain & 836.10 & 0.037 & 0.025 & 0.006 & 0.126 & 0.095 \\
\hline & - & - & - & $(0.005)$ & $(0.048)$ & $(0.054)$ \\
\hline Sweden & 300.80 & 0.077 & 0.022 & 0.007 & 0.103 & 0.046 \\
\hline & - & - & - & $(0.116)$ & $(0.038)$ & $(0.038)$ \\
\hline Switzerland & 309.47 & 0.145 & 0.016 & 0.003 & 0.027 & 0.030 \\
\hline & - & - & - & $(0.012)$ & $(0.025)$ & $(0.022)$ \\
\hline
\end{tabular}

Notes: All other variables are averaged over 1974-1998. Standard deviations are in parentheses. Trade is the total value of bilateral trade between the country and Germany. The exchange rate volatility measure, sd(NER), is calculated by taking the standard deviation of the change of end-of-month $\log$ nominal exchange rate viz. Germany over 1974Q1-1998Q4. Output growth is the quartlery rate. It is calculated by first deseasonalizing deseasonalizing output growth for each country. The interest rate is a quarterly average of the domestic call/money market rate. The inflation rate is calculated from the annual average of the quarterly GDP price deflator. 
Table A.2. Entry and Realignment Dates into EMS

\begin{tabular}{|c|c|c|c|c|c|c|c|c|c|c|}
\hline Date & Germany & Belgium & Denmark & France & Ireland & Netherlands & Italy & Spain & Great Britain & Portugal \\
\hline 1979Q3 & +2.00 & & -2.86 & & & & & $\mathrm{NM}$ & NM & NM \\
\hline 1979Q4 & & & -4.76 & & & & & NM & NM & NM \\
\hline 1981Q1 & & & & & & & -6.00 & NM & NM & NM \\
\hline 1981Q4 & +5.50 & & & -3.00 & & +5.50 & -3.00 & NM & NM & $\mathrm{NM}$ \\
\hline 1982Q1 & & -8.50 & -3.00 & & & & & NM & NM & NM \\
\hline 1982Q2 & +4.25 & & & -5.75 & & +4.25 & -2.75 & NM & NM & NM \\
\hline 1983Q1 & +5.50 & +1.50 & +2.50 & -2.50 & -3.50 & +3.50 & -2.50 & $\mathrm{NM}$ & NM & $\mathrm{NM}$ \\
\hline 1985Q3 & +2.00 & +2.00 & +2.00 & 2.00 & 2.00 & +2.00 & -6.00 & NM & NM & NM \\
\hline 1986Q2 & +3.00 & +1.00 & +1.00 & -3.00 & & +3.00 & & NM & NM & NM \\
\hline 1986Q3 & & & & & -8.00 & & & NM & NM & NM \\
\hline 1987Q1 & +3.00 & +2.00 & & & & +3.00 & & $\mathrm{NM}$ & NM & NM \\
\hline 1990Q1 & & & & & & & -3.86 & & NM & NM \\
\hline 1992Q3 & +3.50 & +3.50 & +3.50 & +3.50 & +3.50 & +3.50 & -3.50 & +3.50 & +3.50 & +3.50 \\
\hline 1992Q3 & & & & & & & & -5.00 & NM & \\
\hline 1993Q1 & & & & & -10.00 & & & & $\mathrm{NM}$ & \\
\hline 1993Q2 & & & & & & & & -8.00 & $\mathrm{NM}$ & -6.50 \\
\hline 1995Q1 & & & & & & & & -7.00 & & -3.50 \\
\hline Entry Date & 1979Q1 & 1979Q1 & 1979Q1 & 1979Q1 & 1979Q1 & 1979Q1 & 1979Q1 & 1989Q1 & 1990Q1 & 1992Q1 \\
\hline Band & \pm 2.25 & \pm 2.25 & \pm 2.25 & \pm 2.25 & \pm 2.25 & \pm 2.25 & \pm 6.00 & \pm 6.00 & \pm 6.00 & \pm 6.00 \\
\hline
\end{tabular}

Note: All realignment values are percentage changes of the currency's bilateral central rate against those currencies who bilateral parities were not realigned. The entry exchange rate band is in percentages. "NM" stands for non-member. Source: Bofinger (2000). 
Table A.3. Unit Root and Cointegration Tests For Quarterly Interest Rates

No Controls

\begin{tabular}{|c|c|c|c|c|}
\hline \multirow[b]{2}{*}{ Country } & \multicolumn{2}{|c|}{ Dickey-Fuller } & \multicolumn{2}{|c|}{$\begin{array}{c}\text { 4th Order Augmented } \\
\text { Dickey-Fuller }\end{array}$} \\
\hline & $\begin{array}{c}\text { Interest } \\
\text { Rates }\end{array}$ & Residuals & $\begin{array}{c}\text { Interest } \\
\text { Rates }\end{array}$ & Residuals \\
\hline Germany & $\begin{array}{c}0.911 \\
(0.043) \\
{[2.079]}\end{array}$ & & $\begin{array}{c}0.865 \\
(0.045) \\
{[2.990]}\end{array}$ & \\
\hline Great Britain & $\begin{array}{c}0.917 \\
(0.036) \\
{[2.301]}\end{array}$ & $\begin{array}{c}0.866 \\
(0.043) \\
{[3.153]}\end{array}$ & $\begin{array}{c}0.917 \\
(0.040) \\
{[2.067]}\end{array}$ & $\begin{array}{c}0.869 \\
(0.053) \\
{[2.468]}\end{array}$ \\
\hline France & $\begin{array}{c}0.815 \\
(0.061) \\
{[3.037]}\end{array}$ & $\begin{array}{c}0.623 \\
(0.081) \\
{[4.644]}\end{array}$ & $\begin{array}{c}0.879 \\
(0.073) \\
{[1.670]}\end{array}$ & $\begin{array}{c}0.839 \\
(0.098) \\
{[1.644]}\end{array}$ \\
\hline Italy & $\begin{array}{c}0.797 \\
(0.065) \\
{[3.122]}\end{array}$ & $\begin{array}{c}0.715 \\
(0.073) \\
{[3.928]}\end{array}$ & $\begin{array}{c}0.904 \\
(0.077) \\
{[1.250]}\end{array}$ & $\begin{array}{c}0.884 \\
(0.086) \\
{[1.363]}\end{array}$ \\
\hline Spain & $\begin{array}{c}0.686 \\
(0.078) \\
{[4.034]}\end{array}$ & $\begin{array}{c}0.650 \\
(0.080) \\
{[4.350]}\end{array}$ & $\begin{array}{c}0.797 \\
(0.105) \\
{[1.944]}\end{array}$ & $\begin{array}{c}0.771 \\
(0.109) \\
{[2.105]}\end{array}$ \\
\hline Netherlands & $\begin{array}{c}0.933 \\
(0.044) \\
{[1.537]}\end{array}$ & $\begin{array}{c}0.710 \\
(0.081) \\
{[3.573]}\end{array}$ & $\begin{array}{c}0.797 \\
(0.105) \\
{[1.944]}\end{array}$ & $\begin{array}{c}0.771 \\
(0.109) \\
{[2.105]}\end{array}$ \\
\hline Switzerland & $\begin{array}{c}0.956 \\
(0.030) \\
{[1.473]}\end{array}$ & $\begin{array}{c}0.931 \\
(0.038) \\
{[1.842]}\end{array}$ & $\begin{array}{c}0.947 \\
(0.032) \\
{[1.694]}\end{array}$ & $\begin{array}{c}0.948 \\
(0.040) \\
{[1.311]}\end{array}$ \\
\hline Sweden & $\begin{array}{c}0.721 \\
(0.087) \\
{[3.206]}\end{array}$ & $\begin{array}{c}0.530 \\
(0.106) \\
{[4.413]}\end{array}$ & $\begin{array}{c}0.831 \\
(0.116) \\
{[1.458]}\end{array}$ & $\begin{array}{c}0.707 \\
(0.151) \\
{[1.938]}\end{array}$ \\
\hline Belgium & $\begin{array}{c}0.922 \\
(0.042) \\
{[1.865]}\end{array}$ & $\begin{array}{c}0.715 \\
(0.087) \\
{[3.277]}\end{array}$ & $\begin{array}{c}0.900 \\
(0.046) \\
{[2.180]}\end{array}$ & $\begin{array}{c}0.833 \\
(0.100) \\
{[1.665]}\end{array}$ \\
\hline Austria & $\begin{array}{c}0.940 \\
(0.038) \\
{[1.570]}\end{array}$ & $\begin{array}{c}0.640 \\
(0.079) \\
{[4.578]}\end{array}$ & $\begin{array}{c}0.876 \\
(0.043) \\
{[2.885]}\end{array}$ & $\begin{array}{c}0.717 \\
(0.099) \\
{[2.864]}\end{array}$ \\
\hline Norway & $\begin{array}{c}0.759 \\
(0.067) \\
{[3.597]}\end{array}$ & $\begin{array}{c}0.731 \\
(0.069) \\
{[3.875]}\end{array}$ & $\begin{array}{c}0.848 \\
(0.080) \\
{[1.904]}\end{array}$ & $\begin{array}{c}0.817 \\
(0.084) \\
{[2.176]}\end{array}$ \\
\hline Portugal & $\begin{array}{c}0.961 \\
(0.042) \\
{[0.935]}\end{array}$ & $\begin{array}{c}0.901 \\
(0.052) \\
{[1.887]}\end{array}$ & $\begin{array}{c}0.848 \\
(0.080) \\
{[1.904]}\end{array}$ & $\begin{array}{c}0.817 \\
(0.084) \\
{[2.176]}\end{array}$ \\
\hline
\end{tabular}

One Lag of Growth, One Lag of Inflation

Four Lags of Growth, Four Lags of Inflation

\begin{tabular}{|c|c|c|c|c|c|c|c|}
\hline \multicolumn{2}{|c|}{ Dickey-Fuller } & \multicolumn{2}{|c|}{$\begin{array}{c}\text { 4th Order Augmented } \\
\text { Dickey-Fuller }\end{array}$} & \multicolumn{2}{|c|}{ Dickey-Fuller } & \multicolumn{2}{|c|}{$\begin{array}{c}\text { 4th Order Augmented } \\
\text { Dickey-Fuller }\end{array}$} \\
\hline $\begin{array}{c}\text { Interest } \\
\text { Rates }\end{array}$ & Residuals & $\begin{array}{c}\text { Interest } \\
\text { Rates }\end{array}$ & Residuals & $\begin{array}{c}\text { Interest } \\
\text { Rates }\end{array}$ & Residuals & $\begin{array}{c}\text { Interest } \\
\text { Rates }\end{array}$ & Residuals \\
\hline $\begin{array}{c}0.917 \\
(0.049) \\
{[1.700]}\end{array}$ & & $\begin{array}{c}0.854 \\
(0.049) \\
{[2.948]}\end{array}$ & & $\begin{array}{c}0.937 \\
(0.051) \\
{[1.248]}\end{array}$ & & $\begin{array}{c}0.884 \\
(0.058) \\
{[1.985]}\end{array}$ & \\
\hline $\begin{array}{c}0.929 \\
(0.037) \\
{[1.931]}\end{array}$ & $\begin{array}{c}0.868 \\
(0.043) \\
{[3.083]}\end{array}$ & $\begin{array}{c}0.955 \\
(0.041) \\
{[1.110]}\end{array}$ & $\begin{array}{c}0.885 \\
(0.053) \\
{[2.189]}\end{array}$ & $\begin{array}{c}0.944 \\
(0.037) \\
{[1.514]}\end{array}$ & $\begin{array}{c}0.794 \\
(0.056) \\
{[3.703]}\end{array}$ & $\begin{array}{c}0.952 \\
(0.045) \\
{[1.075]}\end{array}$ & $\begin{array}{c}0.851 \\
(0.063) \\
{[2.362]}\end{array}$ \\
\hline $\begin{array}{c}0.736 \\
(0.075) \\
{[3.527]}\end{array}$ & $\begin{array}{c}0.345 \\
(0.100) \\
{[6.520]}\end{array}$ & $\begin{array}{c}0.798 \\
(0.094) \\
{[2.151]}\end{array}$ & $\begin{array}{c}0.460 \\
(0.173) \\
{[3.131]}\end{array}$ & $\begin{array}{c}0.712 \\
(0.078) \\
{[3.709]}\end{array}$ & $\begin{array}{c}0.366 \\
(0.103) \\
{[6.149]}\end{array}$ & $\begin{array}{c}0.715 \\
(0.107) \\
{[2.681]}\end{array}$ & $\begin{array}{c}0.359 \\
(0.176) \\
{[3.644]}\end{array}$ \\
\hline $\begin{array}{c}0.583 \\
(0.079) \\
{[5.316]}\end{array}$ & $\begin{array}{c}0.382 \\
(0.095) \\
{[6.503]}\end{array}$ & $\begin{array}{c}0.657 \\
(0.104) \\
{[3.295]}\end{array}$ & $\begin{array}{c}0.355 \\
(0.172) \\
{[3.750]}\end{array}$ & $\begin{array}{c}0.515 \\
(0.090) \\
{[5.394]}\end{array}$ & $\begin{array}{c}0.379 \\
(0.094) \\
{[6.581]}\end{array}$ & $\begin{array}{c}0.638 \\
(0.138) \\
{[2.628]}\end{array}$ & $\begin{array}{c}0.307 \\
(0.177) \\
{[3.914]}\end{array}$ \\
\hline $\begin{array}{c}0.651 \\
(0.080) \\
{[4.380]}\end{array}$ & $\begin{array}{c}0.600 \\
(0.091) \\
{[4.373]}\end{array}$ & $\begin{array}{c}0.725 \\
(0.112) \\
{[2.457]}\end{array}$ & $\begin{array}{c}0.730 \\
(0.150) \\
{[1.810]}\end{array}$ & $\begin{array}{c}0.597 \\
(0.089) \\
{[4.543]}\end{array}$ & $\begin{array}{c}0.524 \\
(0.094) \\
{[5.055]}\end{array}$ & $\begin{array}{c}0.612 \\
(0.145) \\
{[2.675]}\end{array}$ & $\begin{array}{c}0.320 \\
(0.169) \\
{[4.024]}\end{array}$ \\
\hline $\begin{array}{c}0.915 \\
(0.048) \\
{[1.796]}\end{array}$ & $\begin{array}{c}0.674 \\
(0.087) \\
{[3.756]}\end{array}$ & $\begin{array}{c}0.938 \\
(0.044) \\
{[1.435]}\end{array}$ & $\begin{array}{c}0.737 \\
(0.099) \\
{[2.644]}\end{array}$ & $\begin{array}{c}0.936 \\
(0.053) \\
{[1.206]}\end{array}$ & $\begin{array}{c}0.733 \\
(0.084) \\
{[3.196]}\end{array}$ & $\begin{array}{c}1.020 \\
(0.060) \\
{[0.333]}\end{array}$ & $\begin{array}{c}0.727 \\
(0.096) \\
{[2.856]}\end{array}$ \\
\hline $\begin{array}{c}0.966 \\
(0.029) \\
{[1.154]}\end{array}$ & $\begin{array}{c}0.922 \\
(0.041) \\
{[1.919]}\end{array}$ & $\begin{array}{c}0.958 \\
(0.032) \\
{[1.336]}\end{array}$ & $\begin{array}{c}0.947 \\
(0.042) \\
{[1.277]}\end{array}$ & $\begin{array}{c}0.955 \\
(0.029) \\
{[1.546]}\end{array}$ & $\begin{array}{c}0.916 \\
(0.043) \\
{[1.960]}\end{array}$ & $\begin{array}{c}0.960 \\
(0.031) \\
{[1.311]}\end{array}$ & $\begin{array}{c}0.946 \\
(0.046) \\
{[1.182]}\end{array}$ \\
\hline $\begin{array}{c}0.722 \\
(0.089) \\
{[3.132]}\end{array}$ & $\begin{array}{c}0.503 \\
(0.115) \\
{[4.325]}\end{array}$ & $\begin{array}{c}0.835 \\
(0.117) \\
{[1.413]}\end{array}$ & $\begin{array}{c}0.681 \\
(0.167) \\
{[1.911]}\end{array}$ & $\begin{array}{c}0.676 \\
(0.101) \\
{[3.194]}\end{array}$ & $\begin{array}{c}0.476 \\
(0.120) \\
{[4.351]}\end{array}$ & $\begin{array}{c}0.781 \\
(0.119) \\
{[1.843]}\end{array}$ & $\begin{array}{c}0.578 \\
(0.197) \\
{[2.144]}\end{array}$ \\
\hline $\begin{array}{c}0.865 \\
(0.054) \\
{[2.516]}\end{array}$ & $\begin{array}{c}0.346 \\
(0.127) \\
{[5.145]}\end{array}$ & $\begin{array}{c}0.859 \\
(0.058) \\
{[2.454]}\end{array}$ & $\begin{array}{c}0.619 \\
(0.201) \\
{[1.899]}\end{array}$ & $\begin{array}{c}0.893 \\
(0.069) \\
{[1.546]}\end{array}$ & $\begin{array}{c}0.469 \\
(0.119) \\
{[4.480]}\end{array}$ & $\begin{array}{c}0.908 \\
(0.080) \\
{[1.148]}\end{array}$ & $\begin{array}{c}0.328 \\
(0.214) \\
{[3.138]}\end{array}$ \\
\hline $\begin{array}{c}0.938 \\
(0.040) \\
{[1.553]}\end{array}$ & $\begin{array}{c}0.637 \\
(0.081) \\
{[4.486]}\end{array}$ & $\begin{array}{c}0.871 \\
(0.044) \\
{[2.933]}\end{array}$ & $\begin{array}{c}0.703 \\
(0.107) \\
{[2.769]}\end{array}$ & $\begin{array}{c}0.959 \\
(0.039) \\
{[1.061]}\end{array}$ & $\begin{array}{c}0.646 \\
(0.082) \\
{[4.343]}\end{array}$ & $\begin{array}{c}0.898 \\
(0.046) \\
{[2.196]}\end{array}$ & $\begin{array}{c}0.570 \\
(0.114) \\
{[3.762]}\end{array}$ \\
\hline $\begin{array}{c}0.751 \\
(0.067) \\
{[3.703]}\end{array}$ & $\begin{array}{c}0.738 \\
(0.070) \\
{[3.764]}\end{array}$ & $\begin{array}{c}0.844 \\
(0.081) \\
{[1.926]}\end{array}$ & $\begin{array}{c}0.820 \\
(0.085) \\
{[2.126]}\end{array}$ & $\begin{array}{c}0.769 \\
(0.070) \\
{[3.322]}\end{array}$ & $\begin{array}{c}0.743 \\
(0.073) \\
{[3.533]}\end{array}$ & $\begin{array}{c}0.843 \\
(0.083) \\
{[1.887]}\end{array}$ & $\begin{array}{c}0.833 \\
(0.089) \\
{[1.880]}\end{array}$ \\
\hline $\begin{array}{c}0.938 \\
(0.048) \\
{[1.279]}\end{array}$ & $\begin{array}{c}0.749 \\
(0.102) \\
{[2.468]}\end{array}$ & $\begin{array}{c}1.015 \\
(0.056) \\
{[0.275]}\end{array}$ & $\begin{array}{c}1.145 \\
(0.131) \\
{[1.102]}\end{array}$ & $\begin{array}{c}0.890 \\
(0.063) \\
{[1.755]}\end{array}$ & $\begin{array}{c}0.727 \\
(0.093) \\
{[2.929]}\end{array}$ & $\begin{array}{c}0.956 \\
(0.081) \\
{[0.538]}\end{array}$ & $\begin{array}{c}0.545 \\
(0.163) \\
{[2.787]}\end{array}$ \\
\hline
\end{tabular}

Notes: The columns labeled "Interest Rates" shows autocorroelation coefficients for countries' quarterly call money rate. The columns labeled "Residuals" show autocorrelation

coefficients for the fitted residuals of a regression of national on German interest rates. Heteroscedasticity-robust standard errors are in parentheses. T-ratios for the null-hypothesis

of a unit coefficient are in squared brackets. The 5\% critical value for rejection of null of unit root is 3.17 for columns labeled "Interest rates" and 3.27 for columns labeled "Residuals". 

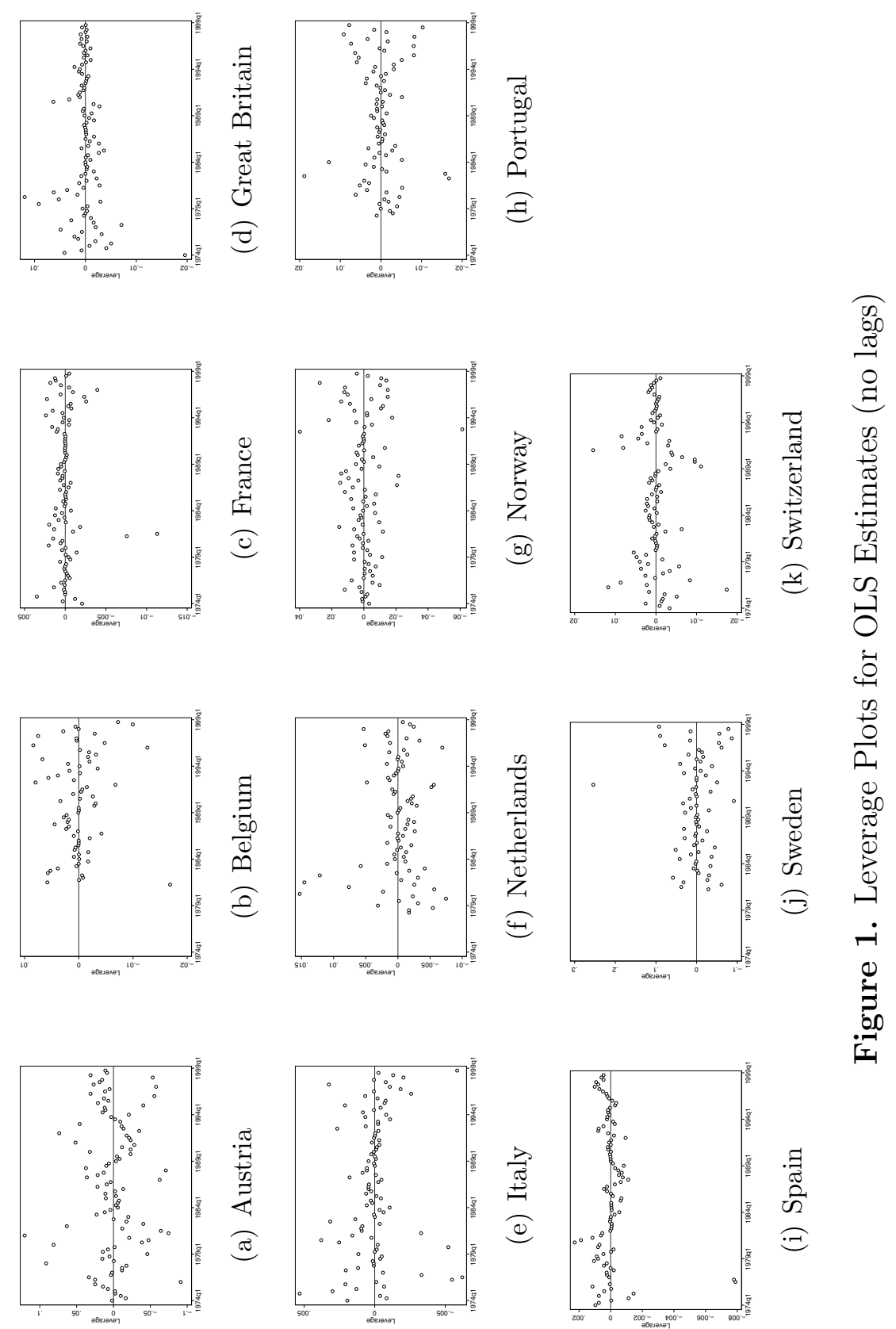

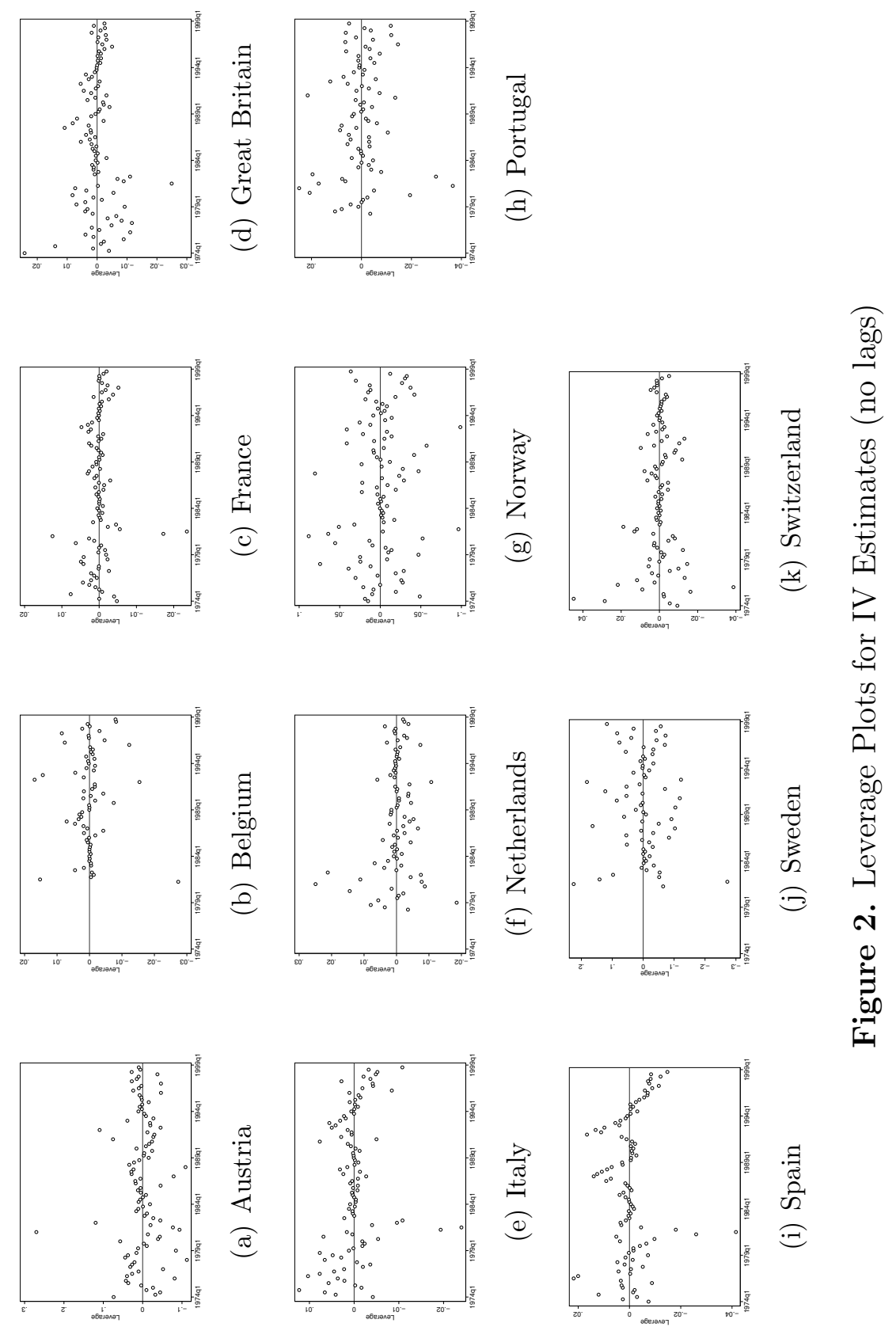